\title{
RE-INTERPRETING THE BODRUM CASTLE UNDERWATER ARCHAEOLOGY MUSEUM: SPATIAL TRANSFORMATION AND EXHIBITION DESIGN STRATEGIES
}

\section{BODRUM KALESI SUALTI ARKEOLOJI MÜZESINII YENIDEN YORUMLAMAK: MEKÂNSAL DÖNÜŞÜM VE SERGI TASARIM STRATEJILERI}

\author{
Makale Bilgisi Article Info \\ Başvuru: 21 Kasım 2021 Received: November 21, 2021 \\ Hakem Değerlendirmesi: 22 Kasım 2021 Peer Review: November 22, 2021 \\ Kabul: 11 Aralık 2021 Accepted: December 11, 2021
}

DOI : $10.22520 /$ tubaked2021.24.009

\section{Seray TÜRKAY COŞKUN * - Esatcan COŞKUN **}

\section{ABSTRACT}

The Bodrum Castle was built by the Order of Knights of Saint John at the beginning of the 15th century. The Castle, situated within a first-degree archaeological site, is one of the most visited museums in Turkey with its underwater archaeology collection. Throughout the processes of its transformation into a museum, the authentic characteristics of the medieval castle have been overshadowed by the urges and challenges to display and preserve an underwater archaeology collection and by the practical necessities of serving as a museum.

An architectural conservation project of the Bodrum Castle was developed between 2014-2016 and restoration implementations have been conducted in three stages since 2018, which were recently completed in the summer of 2021. This study introduces the analyses of problems in the functional and spatial organization of the museum and discusses critical interventions on cultural properties to be used as museum spaces. By re-assessing the Bodrum Castle as a monumental building and as a museum, it presents thematic frameworks, spatial formation strategies and exhibition approach employed in the processes of museum design and implementation.

Keywords: Bodrum Castle, interpretation, monumental building, underwater archaeology, museum, spatial transformation, exhibition design.

\footnotetext{
Asst. Prof. Dr., TED University Department of Architecture.

e-posta: seray.coskun@tedu.edu.tr

ORCID: 0000-0003-1696-7921

** Ph.D. Candidate, Middle East Technical University, Department of Architecture; Adjunct Faculty, TED University, Department of Architecture e-posta:esatcan.coskun@tedu.edu.trＯORCID: 0000-0002-2625-985X

This study benefits from the authors' research and practice conducted within the scope of the museum and exhibition design project on behalf of the architecture and design office Stüdyo Nüve as part of the architectural conservation of the Bodrum Castle Underwater Archaeology Museum. We would like to thank Umut Bilgiç and the architectural conservation project team ANB Architects, for their collaboration and immense efforts in completing and realizing the project. We were very fortunate to work with Sinan Cem Kizıl throughout the design process within which he meticulously modeled not only the Castle but also each and every unique artifact in the collection to be displayed.
} 


\section{ÖZET}

Bodrum Kalesi, 15. yüzyılın başlarında St. John Şövalyeleri tarafından inşa edilmiştir. Birinci derece arkeolojik sit alanı içinde yer alan Kale, barındırdığı sualtı arkeolojisi koleksiyonuyla birlikte Türkiye'nin en çok ziyaret edilen müzelerinden biridir. Müzeye dönüşüm süreçleri boyunca, bu anıtsal yapının ortaçağ kalesine özgü karakteri, sualtı arkeolojisi koleksiyonunu sergileme ve korumaya ilişkin zorlukların ve bir müze olarak hizmet etmenin getirdiği kullanıma ve işletmeye yönelik gerekliliklerinin gölgesinde kalmıştır.

Bodrum Kalesi için 2014-2016 yılları arasında bir mimari koruma projesi geliştirilmiş olup, restorasyon uygulamaları 2018 yılından itibaren üç aşamada yürütülmüş ve yakın zamanda 2021 yazında tamamlanmıştır. Bu çalışma, müzenin işlevsel ve mekânsal organizasyonundaki sorunları ve müze mekanı olarak kullanılmak üzere dönüştürülen kültür varlığı niteliğindeki yapılar üzerindeki kritik müdahaleleri tartışı. Bodrum Kalesi'ni anıtsal bir yapı ve bir müze olarak yeniden değerlendirerek, müze tasarım ve uygulama süreçlerinde benimsenen tematik çerçeveleri, mekânsal dönüşüm stratejilerini ve sergileme yaklaşımını sunar.

Anahtar Kelimeler: Bodrum Kalesi, yorumlama, anıt yapı, sualtı arkeolojisi, müze, mekânsal dönüşüm, sergi tasarımı. 


\section{INTRODUCTION}

The complexities involved in assessing historic buildings as heritage sites and their conversion to museums is manifold. When this conversion expands beyond the conservation, interpretation and presentation of the historic building itself by its heritage status to include the processes of collecting, preserving and displaying a contextually, historically and thematically discrete collection of objects, the challenges multiply by the field emerging in-between history, archaeology, conservation, adaptive reuse, engineering, museography (museum practice), museology (museum studies), architecture and design. The Bodrum Castle presents an example of this intricate field of research and practice as the Castle's "musealization" was triggered by the formation of a unique collection, which is of underwater archaeology.

The International Council of Museums (ICOM) defines musealization as a "scientific process, necessarily includes the essential museum activities: preservation (selection, acquisition, collection management, conservation), research (including cataloging) and communication (via exhibition, publications, etc.)" (Desvallées and Mairesse 2010: 51). Through this process, the objects or things are abstracted from their natural and cultural contexts and re-situated into the museal field as "museum objects" (Desvallées and Mairesse 2010: 50). For the case of the Bodrum Castle, the spatial transformation and gradual restoration of the Castle were intertwined with the conservation and exhibition of underwater archaeology. In other words, the building and the collection are simultaneously transformed into museum objects. Since the early 1960s, both the Bodrum Castle as built heritage and the objects of underwater heritage separated from their original contexts yet, physically and semantically united through the process of musealization. This study aims at discussing museum design as a research and practice integrated to the decision making and implementation processes of architectural conservation interventions based on the applied case of the Bodrum Castle Underwater Archaeology Museum.

The Bodrum Castle is a $15^{\text {th }}$ century fortified structure the architectural formation of which is underlain by Gothic principles. Built by the Knights of Saint John,

\footnotetext{
The terms musealization, museumization, museumification, or museification are used interchangeably to define the processes of transforming historic buildings, sites and even cities into museums. See, Key Concepts of Museology by ICOM (Desvallées and Mairesse 2010: 50-52). For more on the content and expanded context of musealization see, Pınar Aykaç, "Musealisation as an Urban Process: The Transformation of Sultanahmet District in Istanbul's Historic Peninsula," unpublished Ph.D. Dissertation, UCL Bartlett School of Architecture, London, 2017.
}

the Castle is situated within a first-degree archaeological site $^{2}$ and included in the tentative list of UNESCO World Heritage $^{3}$. Even though the Bodrum Castle widely known and visited as an underwater archaeology museum, the Castle embodies a multi-layered context. As the result of a 60-year-long process of its transformation to an underwater archaeology museum, the architectural integrity of the Castle as a monumental building is overshadowed by the spatial, functional and technical necessities of functioning as a museum space.

The architectural conservation project of the Bodrum Castle developed between 2014-2016 includes (1) the restoration decisions and interventions of cultural properties such as fortified and bastioned walls forming the defenses, towers, and other buildings that constitute the monumental identity of the Castle, (2) the assessment of later additions to be removed or reused, (3) the functional, spatial and thematic re-organization of museum and the design of exhibitions, (4) the landscape design of open spaces in the Castle such as moats, courts, and baileys, and (5) the structural, electrical and mechanical engineering, and infrastructure projects within the scope of above mentioned studies. The restoration implementations in the Bodrum Castle have been conducted in three stages since 2018 and recently completed in the summer of 2021.

One of the main inputs guiding the architectural conservation studies has been the spatial and physical articulations in the Bodrum Castle due to its refunctioning as "a museum space" by being transformed into an Underwater Archeology Museum. The unique character of Bodrum Castle as a monument and as a museum (space) necessitated a redefinition of the scope of the conservation project, which expanded beyond the Castle's restoration as a monumental building to include the re-consideration and re-organization of the Castle as a museum. For this reason, studies in restoration and museology were developed in reference to one another by embracing an integrated and interdisciplinary approach to interpret, present and conserve the historical, architectural, structural, and spatial values of the Bodrum Castle as a monumental building and to design it as a museum of multi-layered spaces of display.

\footnotetext{
The Bodrum Castle is under protection by the Turkish Legislation for Preservation of Cultural and Natural Property, Law No: 2863. The Castle was registered as an "immovable cultural property to be preserved" by the decision of Superior Council for Immovable Antiquities and Monuments dated $07 / 03 / 1986$ and numbered 2031. It stays also within the "1st degree archaeological site" which was defined by the decision of the same Council dated 03/07/1987 and numbered 3492.

3 See, https://whc.unesco.org/en/tentativelists/6121/ (Last accessed: 15/11/2021).
} 
This study focuses on the Bodrum Castle Underwater Archaeology Museum and analyzes problems related to the functional and spatial organization of the museum in castle-scale as well as critical conditions resulting from the transformation of various spaces within the Castle to accommodate and serve as "museum spaces." Based on these analyses and observations developed as part of museological research and design studies conducted in parallel with architectural conservation project, it presents thematic frameworks, spatial formation strategies and exhibition design approach employed in the re-interpretation of the Bodrum Castle as a monumental building and as a museum.

\section{ANALYZING THE BODRUM CASTLE}

Regarding the intricacy of the historical context and the architectural program that the Bodrum Castle is identified with, a spatio-temporal analysis of the Castle was fundamental to observe, and thus re-define, the critical limits in its musealization as well as to assess its heritage value. The challenges introduced by the richness of historical, spatial and functional superimpositions within the unique context of the Castle were acknowledged by studying the Bodrum Castle as "a multi-layered context" and as "an underwater archaeology museum."

\section{Bodrum Castle in History: Understanding the Castle as a Multi-Layered Context}

Multi-layeredness manifests itself as an identity of historically stratified contexts where traces and remains of time materialized as changes in events, conditions, meanings, and uses in different intervals become visible (Bilgin Altınöz 2002: 1-4). Researching into the multilayeredness of the Bodrum Castle was significant not only to produce a thorough restitution project ${ }^{4}$ as a foundation

\footnotetext{
The term "restitüsyon projesi" is translated as "restitution project" in the English version of the Law on the Conservation of Cultural and Natural Property (2863) by the Ministry of Culture and Tourism published in Official Gazette on 23/07/1983 number: 18113 - see, https://kvmgm.ktb.gov.tr/TR-43249/lawon-the-conservation-of-cultural-and-natural-propert-html (Last accessed: 15/11/2021). Bilgin Altınöz, Şahin Güçhan, Ayhan, and Bakırer define "restitüsyon projesi" as "a systematic research based on the assessment of archival documents and a comparative study with buildings and related with the building showing the different stages in the life of the building and trying to reach to an original scheme" (2011: 4). Emphasizing the necessity of preparing a restitution project prior to the evaluation of the historic, architectural and cultural values of the building, they discuss different terms adopted for this particular methodological study in conservation projects including "reconstitution," "reconstruction drawing," "restituzione graphica" and suggest the term "graphic restitution project" for the translation of the term "restitüsyon projesi" in Turkish (Bilgin Altınöz, Şahin Güçhan, Ayhan, Bakırer 2011: 4).
}

for restoration but also to understand the superimposition of multiple narratives underlying the Castle's spatial and functional transformations. By mapping critical episodes in the Castle's history it becomes possible to assess to what extent these spatial transformations and superimpositions are, or rather, can be made visible beyond numerous architectural interventions in different levels of scale. It is fundamental to acknowledge the Bodrum Castle with (in) its multi-layered context so as to interpret and present it as a heritage site $^{5}$.

The peninsula where the Castle is located is presumed to be inhabited since ancient times that is also known as Zephyron in the ancient world. However, the earliest architectural remains found in the excavations date back to the 4th century BCE including the wall assumed to be the remnants of the large terrace wall of the palace of Mousolos and the architectural remains evaluated as the parts of the temple of Apollo predicted to be located within the area (Pedersen 2004). There are also other findings from the late antiquity such as the mosaic and other architectural remains, which were unearthed after the demolishment of the infirmary building from the Ottoman period in 1960s. These archeological findings overlap with the period when Halicarnassus was rebuilt as the new capital of the Hecatomnid administration under the rule of Mausolus, Satrap of Caria, indicating that the area was an important part of the city (Diler 2007). There are also traces of an earlier smaller castle walls upon which the Bodrum Castle was built (Newton 1862; Wiener 1966), which also demonstrates that the area was used later as a base probably by Byzantines or Turks in parallel with its geographical advantages.

The Bodrum Castle also known as St. Peter's Castle was built by the Order of Knights of Saint John at the beginning of the $15^{\text {th }}$ century. There are different interpretations regarding the exact date for the beginning of construction oscillating between the years 1402 and 1415 (Newton 1862: 645; Wiener 1966: 92; Kalças 1989: 3$)^{6}$. Under the rule of the grand master (magnus magister) Philibert de Naillac, German architect Henry Schlegelholt was commissioned for the construction of the Castle (Newton 1862).

\footnotetext{
The processes of interpretation and presentation are essential for heritage conservation, or rather, for the assessment and understanding of objects and/or sites as "heritage". While Tilden (2007) emphasizes "interpretation" as the initial step towards understanding and thus conservation of heritage, Kirshenbatt-Gimblett (1998: 6-7) claims that display or presentation not only shows or speaks about heritage but also mediates and transforms what is brought into heritage and thus it does heritage.

6 The restitution report prepared within the scope of architectural conservation project evaluates 1415 , as suggested by Wiener, as the most probable date for the start of the construction.
} 
Besides the debates on the beginning of construction, the periodization of other construction activities particularly during the period of Saint Jean Knights can be traced by the help of the carved reliefs and coat of arms inscribed on marble blocks embedded within the stone walls of the Castle. These marble blocks, which can be considered among the unique architectural features of the castle, bear the information about the construction date, the commander of the castle, and the grand master of that period as well as the country financed the construction or the personal figure responsible for that part of the construction. This is the reason why the towers within the castle are called the German, Spanish, Italian, French and English Towers.

Along with the detailed documentation of nearly 240 carved reliefs / coat of arms on the castle walls, a comprehensive material and structural analysis was conducted to determine the periods of walls and structures. The Bodrum Castle was also studied in reference to other castles built by the Saint Jean Knights, particularly to the one in Rhodes, by comparing castles' architectural features, construction techniques and materials. Under the light of aforementioned studies, the Bodrum Castle's historical development was identified by four main phases of construction (Fig.1) as follows ${ }^{7}$ :

\section{Saint Jean Knights | Early Construction Period_1415-1480 \\ 2. Saint Jean Knights | Late Construction Period 1480-1522}

3. Ottoman Period_1522-1923

4. Republican Period_1923-current

The general plan formation and silhouette of the castle is actually outlined during the early construction period. The five unique towers of the castle (German, Spanish, Italian, French and English Towers) were built in this phase as well as the Naillac Building (wine and weapons warehouse), Gate Tower, Harbor Tower and some of the structures near the French Tower.

After the siege of Rhodes by Fatih Sultan Mehmed in 1480 , the second main construction phase of the castle began in order to strengthen the defenses against the Ottoman threat. The focal point of that phase was the northern defense line, where a new moat (north moat) and the harbor battery have been added to protect the inner walls from artillery fire. Apart from some additions and fortifications on the western walls, the group of

Brief history and identification of construction phases of the Bodrum Castle benefits from the "Historical Research, Periodization, Comparative Study and Restitution Report" written by Tekin Süllü and Oğuz Bostancı in 2015 within the scope of the architectural conservation project. structures in-between the French and Italian Towers and the Chapel can be assessed as the most important constructions of the second period.

In 1522, Süleyman the Magnificent conquered Rhodes, which also ended the rule of Saint Jean Knights in Bodrum. This conquest caused the Bodrum Castle to loose its former importance and the Castle had been used as a small garrison base by Ottomans between 1522 and 1885 . The construction activity during this period is mostly defined by repairs and restorations besides some smaller additions such as observation towers or base foundations for canons. The most significant and earliest change of the Ottoman period was the transformation of the chapel to a mosque by the addition of a minaret (Evliya Çelebi 2005 [1671]: 211-213).

In 1885, the last artillery unit situated in the castle was decommissioned and the Bodrum Castle lost its original function as a military base (Baykara 1992: 249). In 1895 the Castle was transformed into a prison and a group of new service structures were built. The two crucial additions were health and hygiene related structures such as the Ottoman bath and the infirmary building that was later demolished in 1960s.

During World War I, the castle was exposed to and heavily damaged by the bombardment of a French battleship in 1915, which led to the transfer of the prisoners to inland and the complete evacuation of the castle. The Italians invaded Bodrum after Ottomans lost the war in 1919 and used the castle as headquarters until 1921 when they decided to withdraw all their forces on Anatolia as a result of the success of Turkish Independence War (Galanti 1945: 77-78).

With the establishment of Turkish Republic in 1923, the Ottoman period of the Castle came to an end. However, the Castle remained empty until 1958, except its shorttime usage as a military base during World War II.

The histories of the Castle and underwater archaeology encountered by the interview between the spongediver Kemal Aras and the American journalist Peter Throckmorton in 1958 (Bass 2012: 21). Kemal Aras described a sunken cargo of metal near Cape Gelidonya, which Throckmorton identified as belonging to a bronzeage shipwreck after diving in that area a year later. He sent his findings as a report to the University of Pennsylvania (Bass 2005: 14). This report triggered the first scientific archaeological underwater excavation to be conducted at Cape Gelidonya by George F. Bass in 1960 (Bass 2005: 48-50). One year later, another shipwreck detected by sponge-divers in Yassiada and then excavated by Bass and his team (Bass 2005: 16). 


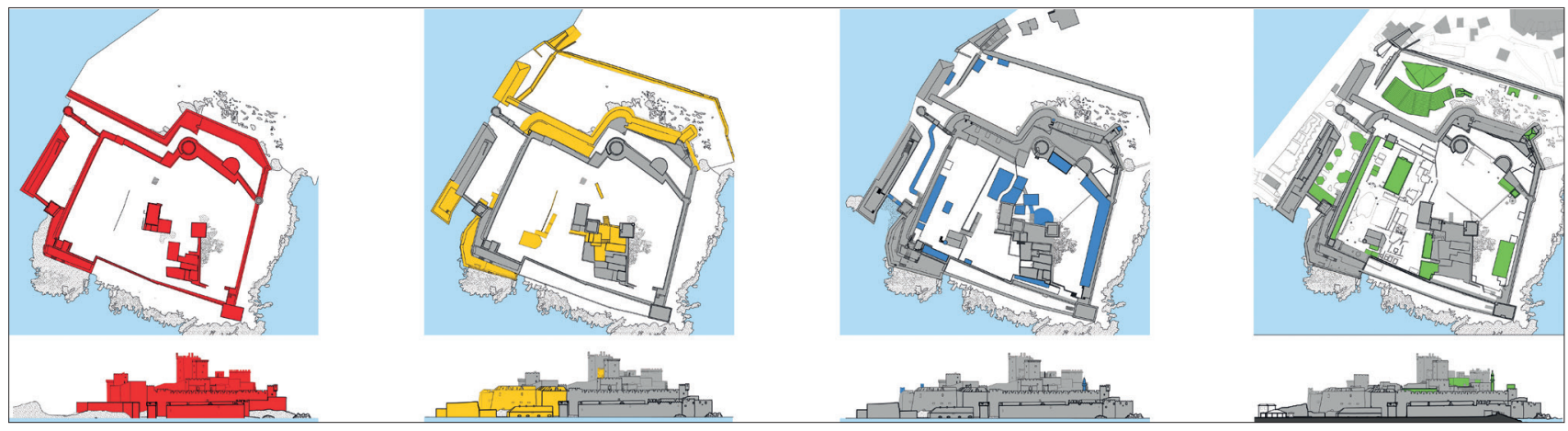

Figure 1: Periodization of the Bodrum Castle in reference to four main phases of construction / Bodrum Kalesi'nin dört ana inşa aşamasl üzerinden dönemlenmesi

During these early days of underwater archeology, Bodrum Castle began to be used as storage for myriad of artifacts found by sponge-divers as well as the findings from the Cape Gelidonya excavation in 1960. With the four glass display cases provided by the Ministry of Education and with funds from George Bass, the first humble exhibition inside the Castle was organized in 1961, which led to the transformation of the Bodrum Castle into an official museum three years later in 1964 (Bass 1996: 9).

As new shipwrecks were identified and more excavations were carried out, the need for storage spaces increased as well as additional space demands emerged for the restoration and documentation of the stored artifacts. The Castle began to be repaired partially and gradually according to emerging spatial needs between 1960 and 1964. After a few years from its declaration as an official museum, the Castle has undergone extensive repairs and restorations throughout the 1960s and 1970s. New buildings began to be constructed in time due to new underwater excavations that required even more space for both exhibition and storage. The largest in scale of later additions appeared in 1983 and 1993 by the construction of two buildings that will accommodate Serçe Limanı "Glass Wreck" exhibition hall and the Late Bronze Age Shipwrecks hall respectively8.

Based on the mapping of four main phases of construction of the Bodrum Castle (Fig.1), the walls, towers, and other buildings qualified as cultural properties constituting the monumental identity of the Castle can be distinguished from later additions as observed in Figure 2.

\footnotetext{
The Serçe Limanı "Glass Wreck" Exhibition Hall was built in 1983 with the decision of Directorate of Antiquities and Museums dated 1979. Late Bronze Age Shipwrecks Hall was built in 1993 by the decision of İzmir No.2 Regional Board for the Preservation of Cultural and Natural Assets.
}

\section{Bodrum Castle Today: Analyzing the Castle as an Underwater Archaeology Museum}

Histories of the Bodrum Castle and underwater archaeology intertwined in the last sixty years through the underwater excavations conducted along the Aegean and Mediterranean shores of Turkey. The transformation of the Bodrum Castle into an underwater archaeology museum and the emergence of underwater archaeology as a scientific discipline can be read in reference to one another. The episodic refunctioning of the Castle as an underwater archaeology museum brought a gradual transformation by partial repairs, restorations, reconstructions and additions. The scale of interventions in order to satisfy the need of space in the processes of transforming into a museum can be observed not only by the restitution study but also by mapping intervened areas on the Castle's aerial view before 1960 as indicated in Figure 3 . The processes of intervention and transformation without a comprehensive architectural conservation plan resulted in a series of problems in different levels of scale.

Based on the series of analysis conducted according to the authenticity (Fig.2), functional distribution (Fig.4 \& 5), museum circulation (Fig.6), and initial observations on cultural properties and later additions, the conditions of which collected in Figure 7, the problems related to functioning and articulation of the Castle as a museum can be summarized as followed:

- Museological and museographical problems

- Disorientations and detours in museum circulation

- Coincidental and unsafe visiting routes

- Lack of thematic sections that can be followed in series or groups of spaces 


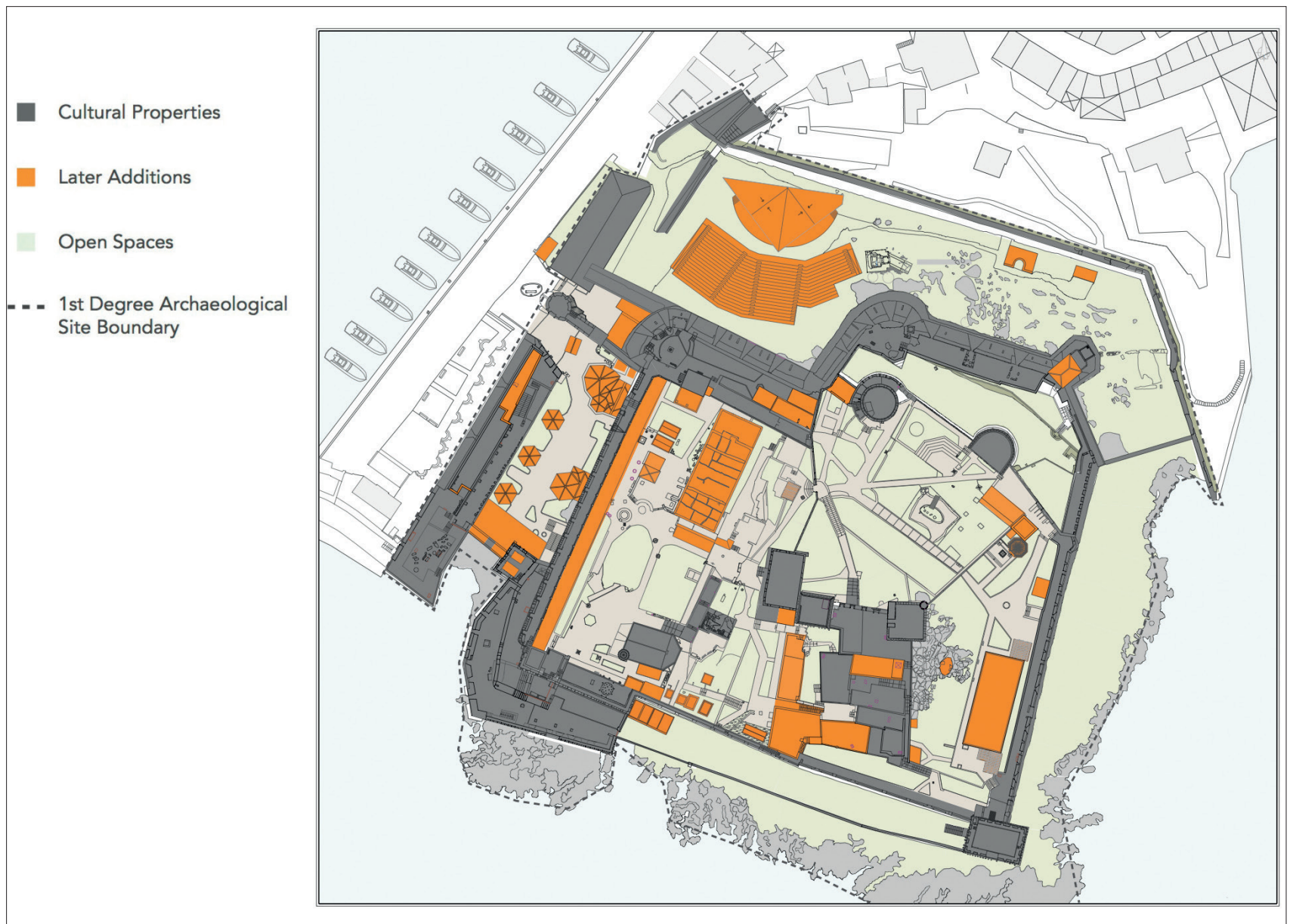

Figure 2: Analysis of building authenticity / Yapı özgünlük analizi
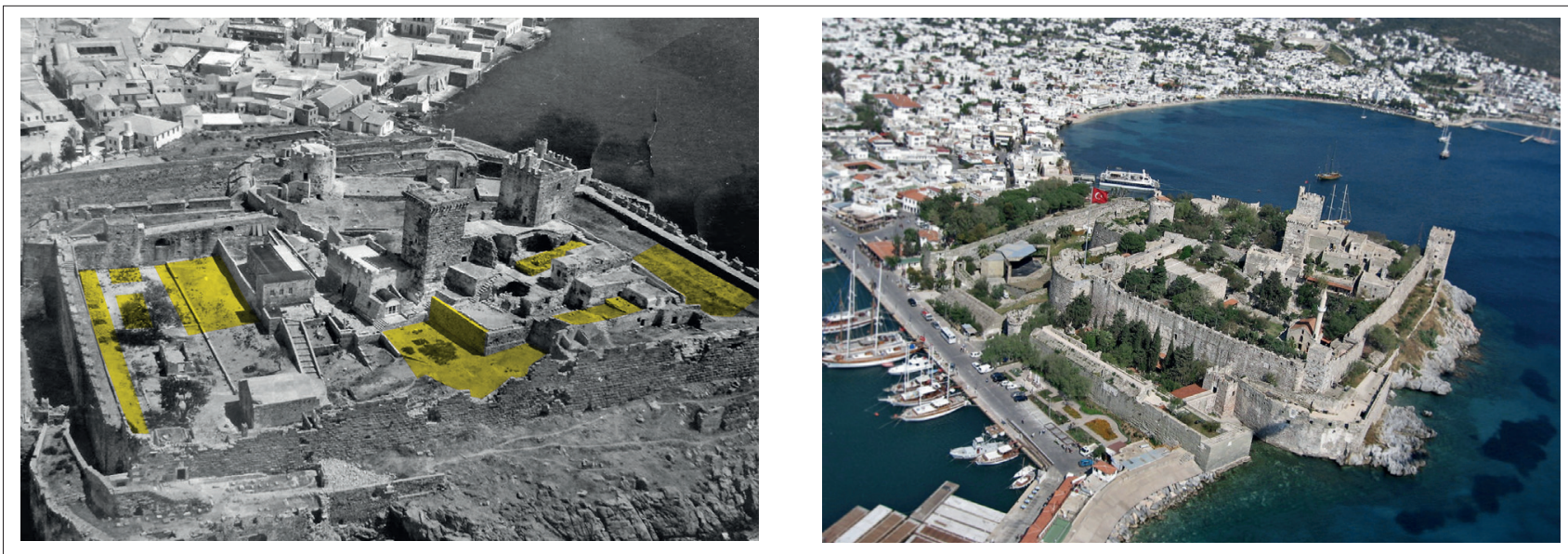

Figure 3: (left) Bodrum Castle in 1964 [ref: restitution report]; (right) Bodrum Castle before restoration / (solda) 1964 yllinda Bodrum Kalesi; (săgda) Restorasyon öncesi Bodrum Kalesi

- Disordered exhibition contents and random exhibition sequences

- Lack of hierarchy between artifacts in display; singular or multiple artifact displays in the same type of display case

- Combining artifacts with dioramas in displays without distinguishing the authentic from the reproduction
- Old display cases insecure and insufficient for the climatic conservation conditions of artifacts

- Spatial, technical and mechanical insufficiencies of conservation laboratories and storages

- Distributed storages 


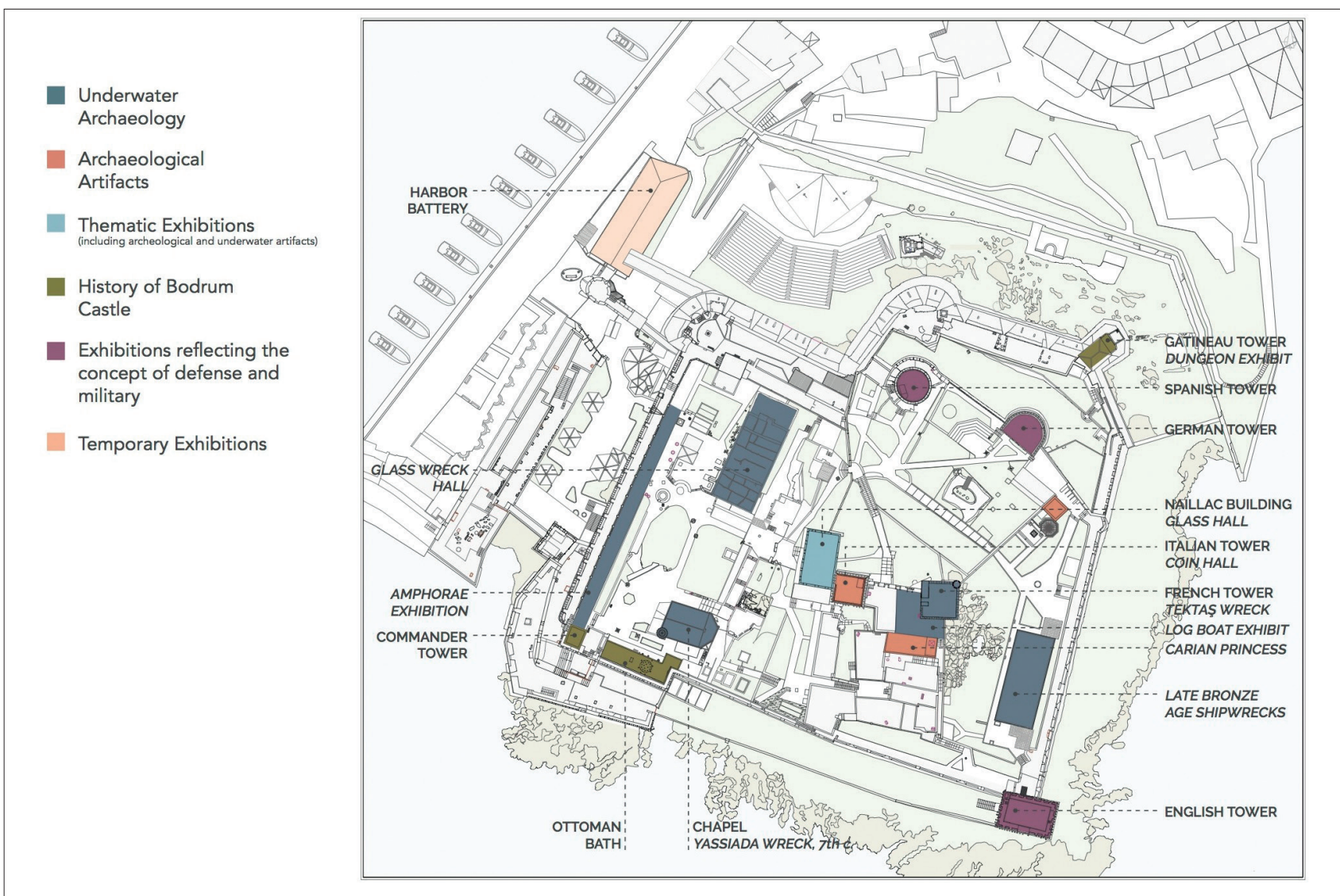

Figure 4: Analysis of museum circulation / Müze dolaşımı analizi

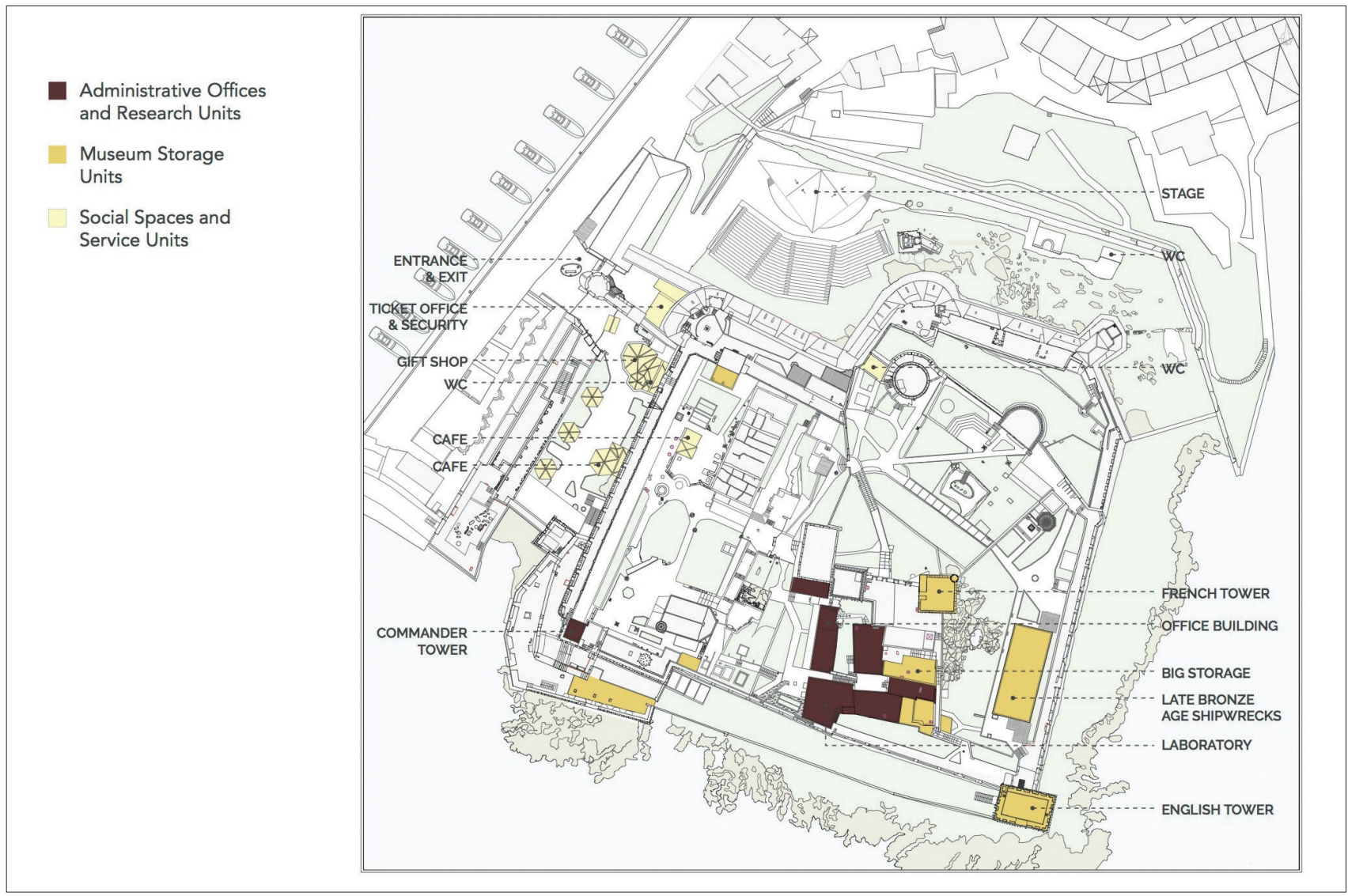

Figure 5: Analysis of functional distribution - exhibition spaces / İslevsel dağılım analizi - sergi mekanları 


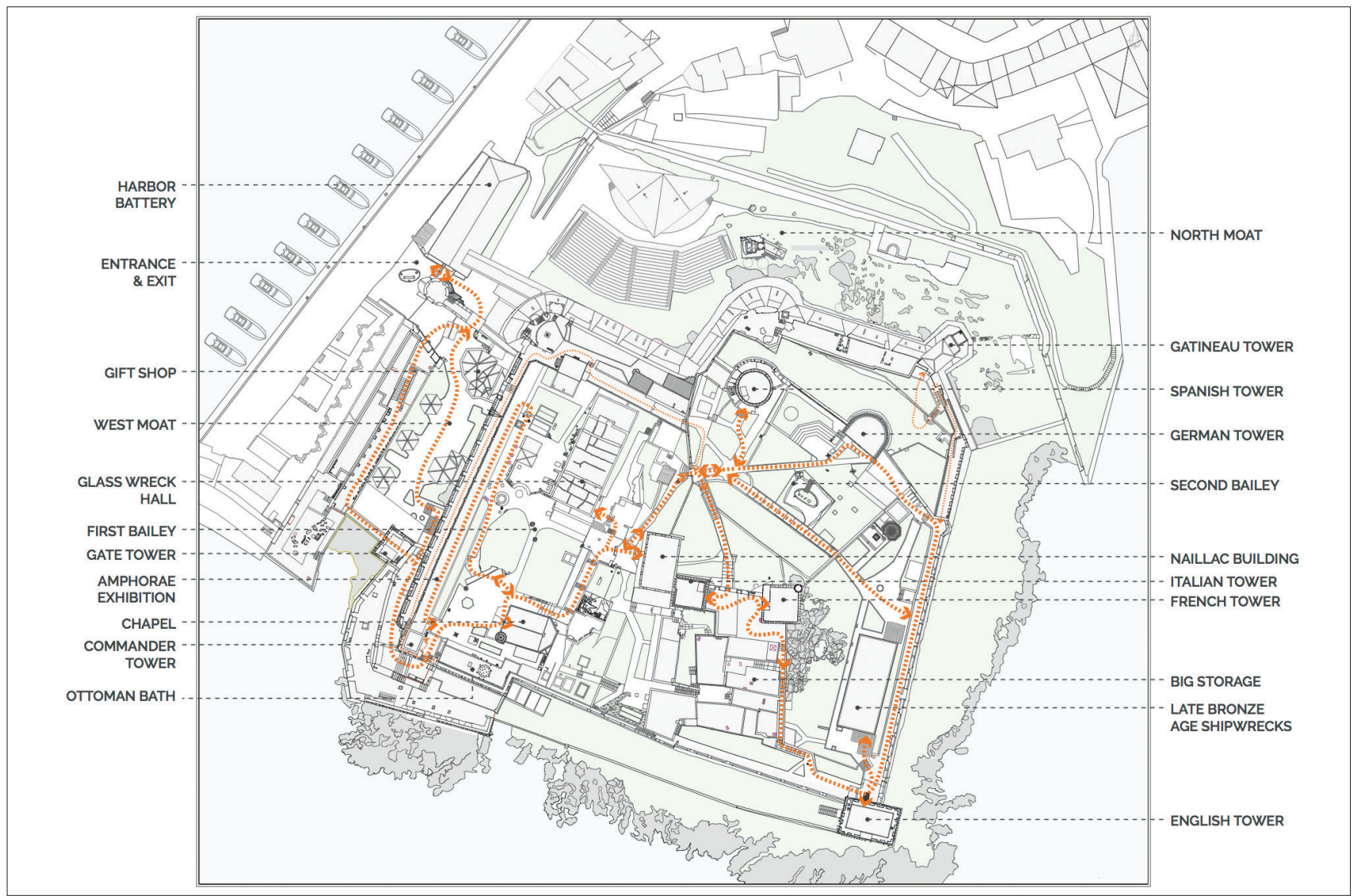

Figure 6: Analysis of functional distribution - managing and service spaces / Işslevsel dağılım analizi - yönteim, müze destek hizmetleri ve servis birimleri

- Challenging transportation of artifacts due to steep slopes within the rocky topography of the Castle

- Unsafe conditions in storing artifacts (such as the use of cisterns under the English Tower as amphorae storage)

- Problems related to the conservation and presentation of cultural properties

- Disregarding of historical and architectural identity of castle spaces in the processes of transformation

- Plastering of interior surfaces of castle walls and/or construction of secondary surfaces within authentic spaces to achieve arguably "ideal" display environments

- Exhibitions introduced for thematic ambiences (such as the interpretation of the English Tower as a medieval banquet hall or the Gatineau tower as a dungeon with mannequins in chains)

- Physical attachment of display cases to medieval castle walls

- Castle spaces excluded from museum visit in order to function as storages
- Problems in the relationship of cultural properties and collection

- Lack of a unified and consistent design approach to govern the relationship of spaces and displays

- Dominance of collections in display over castle spaces in the implementation of exhibitions

- Use of large-scale dioramas and visuals in authentic buildings (such as the partial model of the Byzantine Ship in the Chapel / Mosque and the painting of Halicarnassus on the Chapel's apse)

\section{RE-ASSESSING THE BODRUM CASTLE AS A MONUMENTAL BUILDING AND AS A MUSEUM (SPACE)}

Deriving from historical, spatial and functional analyses and problem observations in different scopes and scales, museological and architectural potentials of the Bodrum Castle were assessed. While the multiplicity of histories, objects and narratives are acknowledged as a basis for constructing a museological approach, intervention strategies were proposed to associate the museological framework with spatial transformations. 


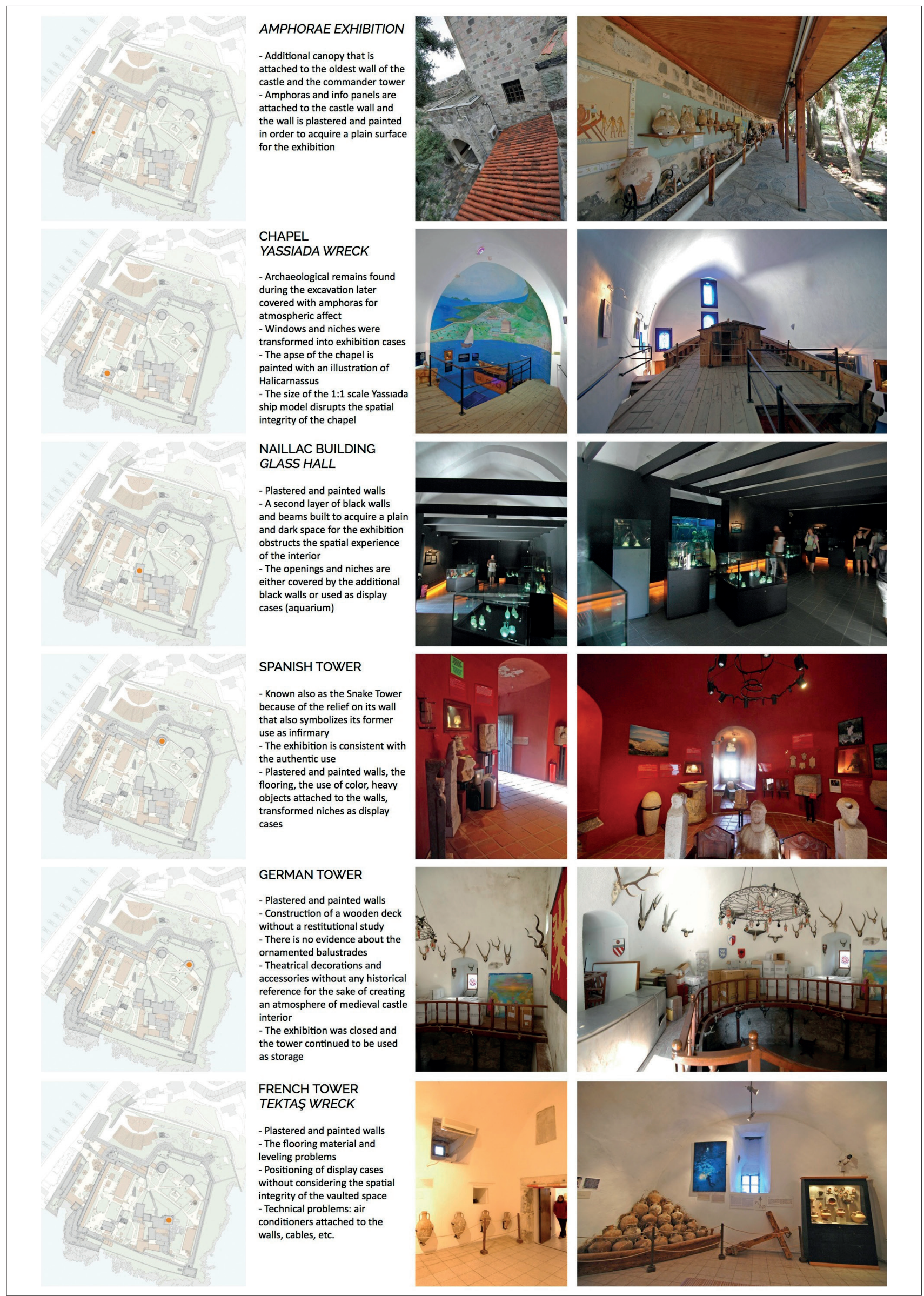

Figure 7a: (a). Problem definitions related to cultural properties and later additions / Kültür varliğl niteliğindeki yapılar ve geç dönem eklerine yönelik problem tespitleri 


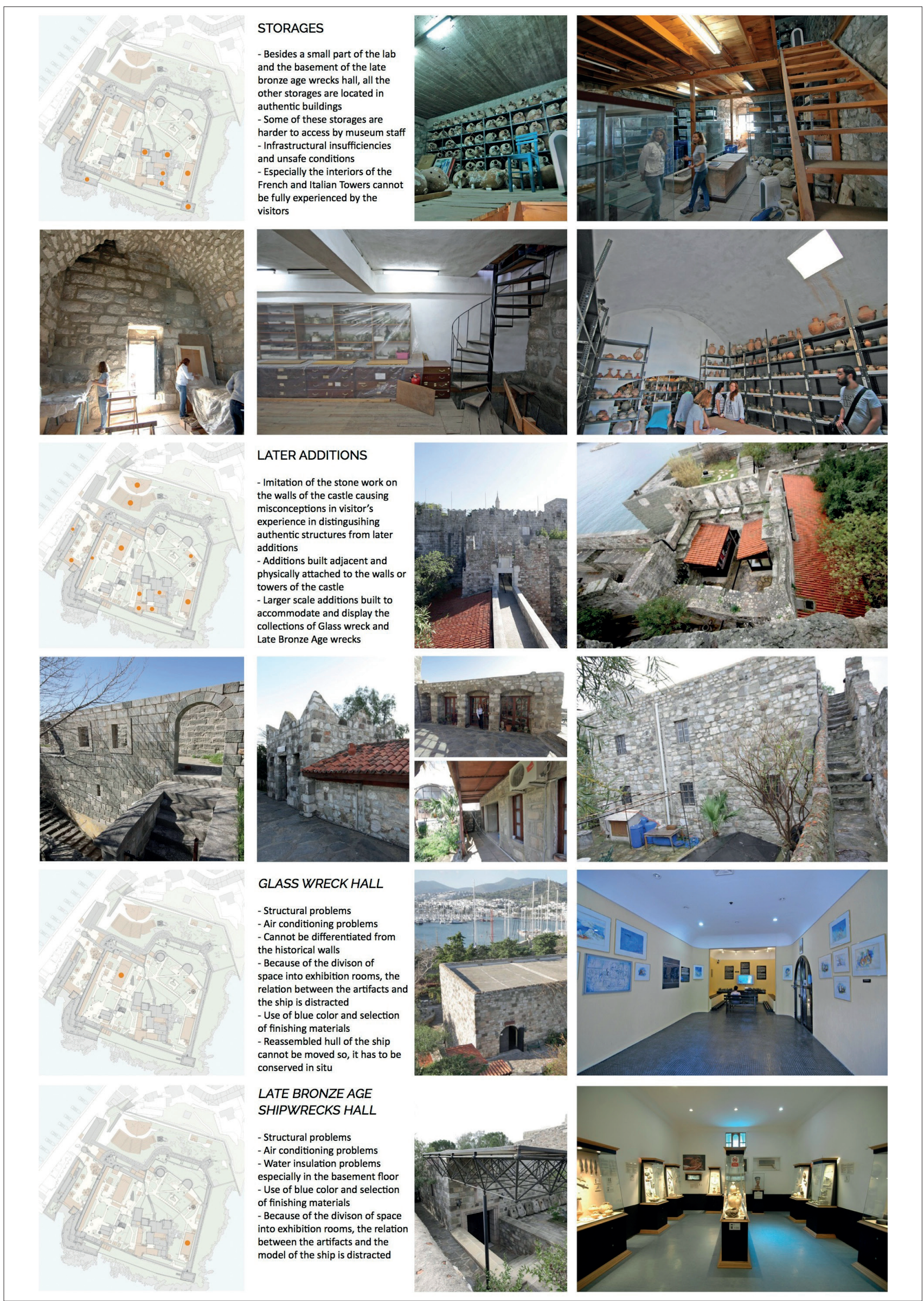

Figure 7b: Problem definitions related to cultural properties and later additions / Kültür varlı̆̆ niteliğindeki yapılar ve geç dönem eklerine yönelik problem tespitleri 


\section{Museological Assessment and Approach}

Bodrum Castle presents a multi-layered context not only due to the physical coexistence and contextual aggregation of structures and remains from different periods but also because of the spatial, functional and historical superimpositions it embodies. The most significant transformation in its recent period was triggered by the Bodrum Castle's reuse as a basis for conducting documentation, conservation and research studies of underwater archaeology and as a storage of artifacts which eventually led to its evolution into an underwater archaeology museum. The Bodrum Castle did not only contribute to the establishment of a worldrenowned collection and museum but also witnessed the disciplinary formation of underwater archaeology. Yet, the transformation into an underwater archaeology museum was architecturally, spatially, functionally and technically demanding and exhaustive for a medieval castle. While the depth of spatial superimpositions increased by the addition of new layers to the Castle's historical richness, many cultural properties distinguishing for the Bodrum Castle, such as the Chapel, the wine and weapons warehouse, the Italian, French, German, English, and Spanish Towers, have lost their historical and spatial integrity and architectural authenticity under the pressure of serving as museum spaces. In addition to series of unplanned interventions to cultural properties, the castle's monumental identity has also been interrupted by numerous later additions constructed as physically attached to existing cultural properties and by individual buildings settled within previously un-built open areas. These later additions, varying in scale from water closet cabins to shipwreck exhibition halls, which were introduced in a fragmented manner according to emerging needs of the museum without a comprehensive conservation plan and reuse strategy, physically damaged the Castle and its architectural elements and morphologically diminished the definition of moats and baileys. In other words, the authentic characteristics of the medieval castle have been overshadowed by the urges and challenges to display and preserve an underwater archaeology collection and by the practical necessities of serving as a museum.

It is claimed that a museological balance should be sustained by acknowledging the multi-layered context and monumental identity of the Bodrum Castle as well as the significance of underwater archaeology collection. In order to achieve a re-definition of the Bodrum Castle as a heritage place and as a contemporary museum and to maintain such a balance between the Castle and the collection, as an initial step, it has been suggested that "Bodrum Castle" should be acknowledged in the museum's title by revising it as "Bodrum Castle
Underwater Archaeology Museum." In order to recover the value of the Bodrum Castle as a monumental building to be conserved and displayed, its historical and architectural authenticity should be made visible along with the underwater archaeology collection.

As "a monumental building" and as "a museum space," the Bodrum Castle embodies a multi-layered context and thus includes multiple narratives and artifacts that are contextually, historically and thematically distinct:

- The Bodrum Castle and its history

- Underwater archaeology

- Archaeological remains and artifacts, dating back to historical periods before the Castle, from Halicarnassus and its close vicinity

- Other archaeological and ethnographic artifacts from different periods and contexts included in the museum inventory by purchases or donations for creating thematic ambiences in exhibition spaces (such as the Ottoman bath or the English Tower interpreted as a medieval banquet hall).

As introduced within the scope of problems, previously the displays were followed in fragments due to the disoriented museum circulation and lack of narrative organization as a result of the piece-by-piece opened exhibition halls. To achieve a consistent museological approach, the abovementioned narratives, artifact collections and the Bodrum Castle itself are questioned in reference to one another. It is decided to propose "umbrella themes" that will coherently regulate specific group of exhibitions and narratives. As a principle, these exhibitions are spatially distinguished so as to render each narrative thematically legible. The oscillating relations between "old and new," "land and water," "space and object," and "historic and thematic" frame the museological approach within which different modes of display are developed based on varying associations to be constructed between spaces, objects and narratives. The definition of thematic frameworks and order of exhibitions will be explained further under the title "Reorganizing the Bodrum Castle as a Museum."

\footnotetext{
9 Arguably, today the museum's title still remains as "The Bodrum Museum of Underwater Archaeology." See; https://www. ktb.gov.tr/EN-120300/the-bodrum-museum-of-underwaterarchaeology.html (Last accessed: 15/11/2021).
} 


\section{Architectural Intervention and Spatial Transformation Strategies}

Bodrum Castle presents a multi-layered context where each exhibition has to respond a unique "space-objectnarrative" association. In reference to castle-scale conservation intervention decisions (Fig.8), the spatial potentials and reuse possibilities offered by the Castle were questioned and evaluated as fundamental to integrate the museological framework with the spatial reorganization of the museum. The problems and potentials determined in the use, physical condition, architectural expression, and functional organization of spaces in the Castle necessitate a manifold approach, which includes interventions in different levels of scale. The architectural intervention and spatial transformation decisions that are developed by embracing an integrated approach between architectural conservation and museum design can be explained in three groups:

- Spatial transformation of buildings and building groups qualified as cultural properties:

While major decisions on conservation of cultural properties are defined within the framework of castlescale interventions, "spatial transformations" of these buildings and building groups are defined by design and reuse decisions proposed according to their architectural characteristics, histories, and locations. Buildings and building groups qualified as cultural properties within the Bodrum Castle (Fig.8) differ from one another considering their architectural qualities, spatial experiences that they suggest, their uses through different historical periods and their recent positions following the Castle's transformation into a museum as exhibition spaces and administrative or service spaces such as offices and storages. Reduced to serve as "museum spaces," it is aimed to recover and represent these cultural properties as essential parts expressive of the monumental identity of the Bodrum Castle. Toward a new museum organization, cultural properties are assessed based on their architectural, historical and spatial values and potentials and principle decisions are outlined as followed:

- Chapel and the Ottoman Bath: These two buildings are unique due to their original functions and thus typologically differentiate from other buildings in the Castle as each refer and represent different historical periods of the Castle. It is suggested to assess these two buildings with their architectural, spatial and functional integrity so as to display themselves rather than reusing their interiors as potential spaces to exhibit artifacts.

- Towers: As the typical elements emphasizing the

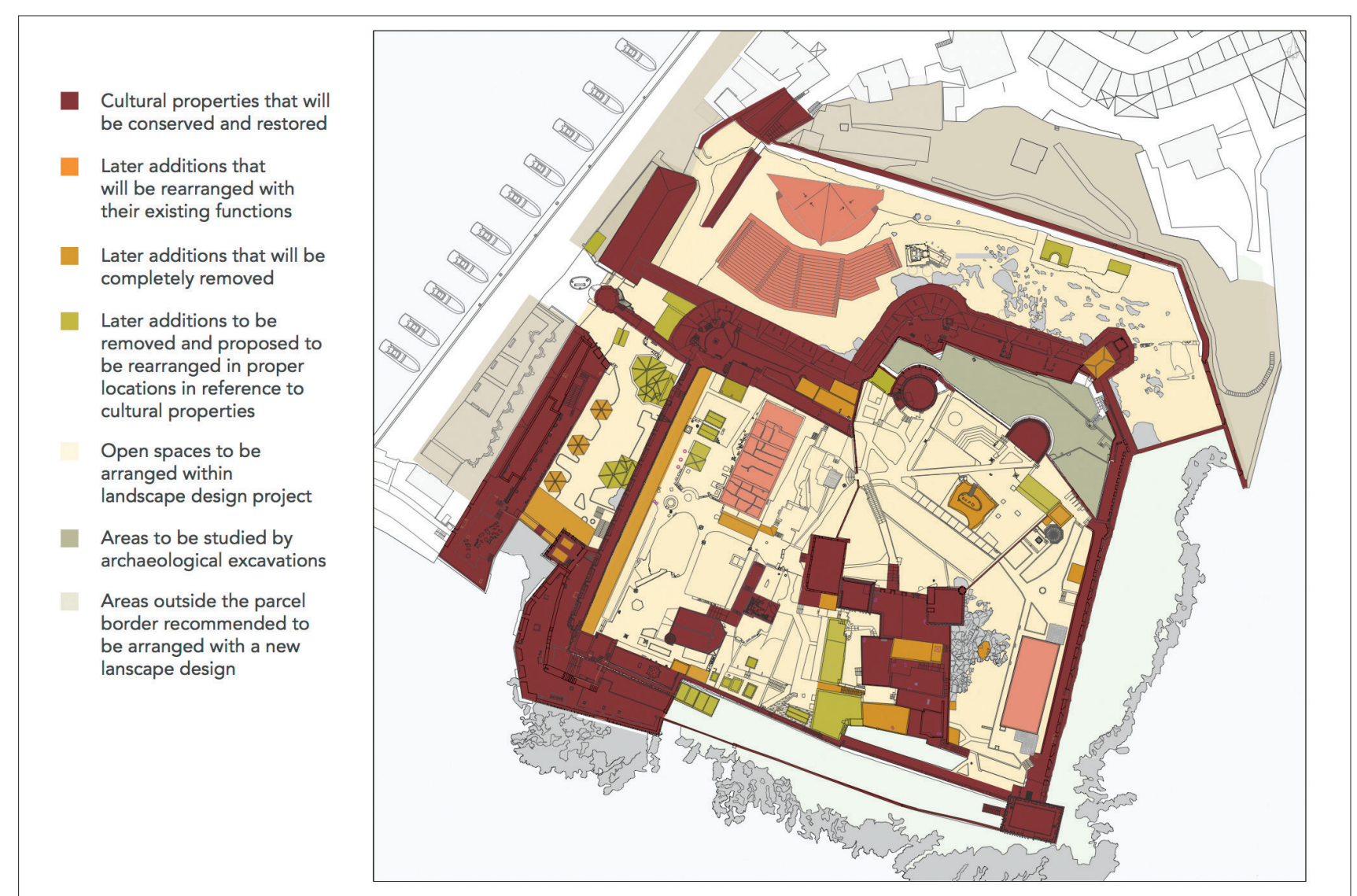

Figure 8: Castle-scale conservation intervention decisions / Kale ölçeğinde koruma müdahale kararları 
Castle's architectural character the towers are the most powerful elements of the Castle as a display object. Since The Order of the Knights of Saint John was a multinational organization, each Order has its own tower by its own style. They are also expressive with their interiors and have the potential to accommodate various spatial superimpositions by the introduction of exhibitions. Regarding the multiplicity of narratives that the Bodrum Castle offers, each tower's potential as an exhibition space is assessed together with museum experts in reference to museum collection and in relation to the possible route(s) to be followed by visitors within a consistent narrative framework.

- Other buildings and building groups qualified as cultural properties: This group is composed of smaller scale buildings that are relatively modest in their architectural expression. Most of these buildings are completed and/or expended in time without any restitution study. Therefore the ones that are inaccurately completed, expended or transformed will be removed within the scope of architectural conservation project to recover the integrity of the Castle. The ones that managed to conserve their integrity will be restored and continue to be used as administrative spaces. Two among this group of buildings (one is the wine and weapons storehouse and the other is located within the Keep that is defined by the French and Italian Towers) are distinguished by their scale and spatial characteristics and thus assessed as potential exhibition spaces.

- Walls and Baileys: The architectural and monumental identity of the Bodrum Castle cannot only be understood by towers, buildings and the series of enclosed spaces within but by the open space formations. Baileys, moats and walls are significant in the Castle's spatial organization as well as in expressing its visual grandeur. In this regard, the moats and baileys are considered as open-air exhibition spaces while landscape decisions aimed at highlighting the Castle's value as a monumental display object and as an activity space (Fig.9).

- Architectural interventions and spatial transformations of later additions:

Later additions that are constructed through the processes of the Bodrum Castle's transformation into an underwater archaeology museum are mostly removed considering their physical conditions as being attached to cultural properties, their structural and functional

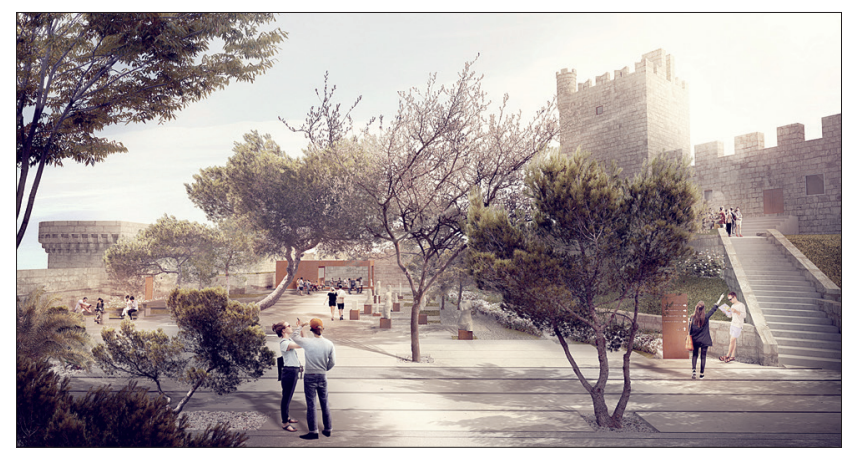

Figure 9: Upper bailey and open-air exhibition proposal / Üst avlu ve açı hava sergi önerisi

insufficiencies, and weakness in their architectural qualities. Two buildings among these later additions, which accommodate two significant underwater archaeology exhibitions (Serçe Limanı "Glasswreck" and Uluburun Shipwreck exhibitions see, Fig.5 \& Fig.8), are decided to be sustained and renovated according to advices of the scientific board and suggestions resulted from the International Bodrum Castle Workshop ${ }^{10}$ as these two buildings and thus the shipwreck exhibitions were associated with the Castle in the collective memory of Bodrum.

- New building proposals:

Within the scope of architectural conservation project, a number of small scale light-weight structures are proposed to serve for museum visitors, such as kiosks for information and ticketing, cafés, gift shop, and water closets (Fig.10-11). In order to respond the technical needs of storage spaces and conservation laboratories, a linear group of buildings is proposed in the north moat (Fig.11). By this relatively larger addition, the storages previously fragmented and distributed within the Castle

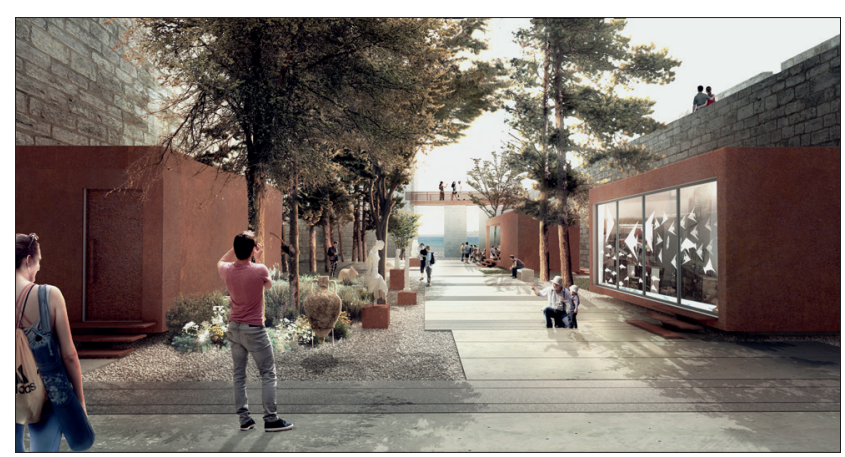

Figure 10: Proposal for the west moat with service units and intended visual connection with the sea after restoration / Bat hendeğinde yer alacak servis birimleri ve restorasyon sonrast denizle görsel ilişkinin yeniden kurulması önerisi

International Bodrum Castle Workshop was collaboratively organized by Bodrum Municipality, Chamber of Architects Bodrum Agency and Foundation of Mediterranean Countries Academy (Akdeniz Ülkeleri Akademisi Vakfi) on 12-13 December 2017. 


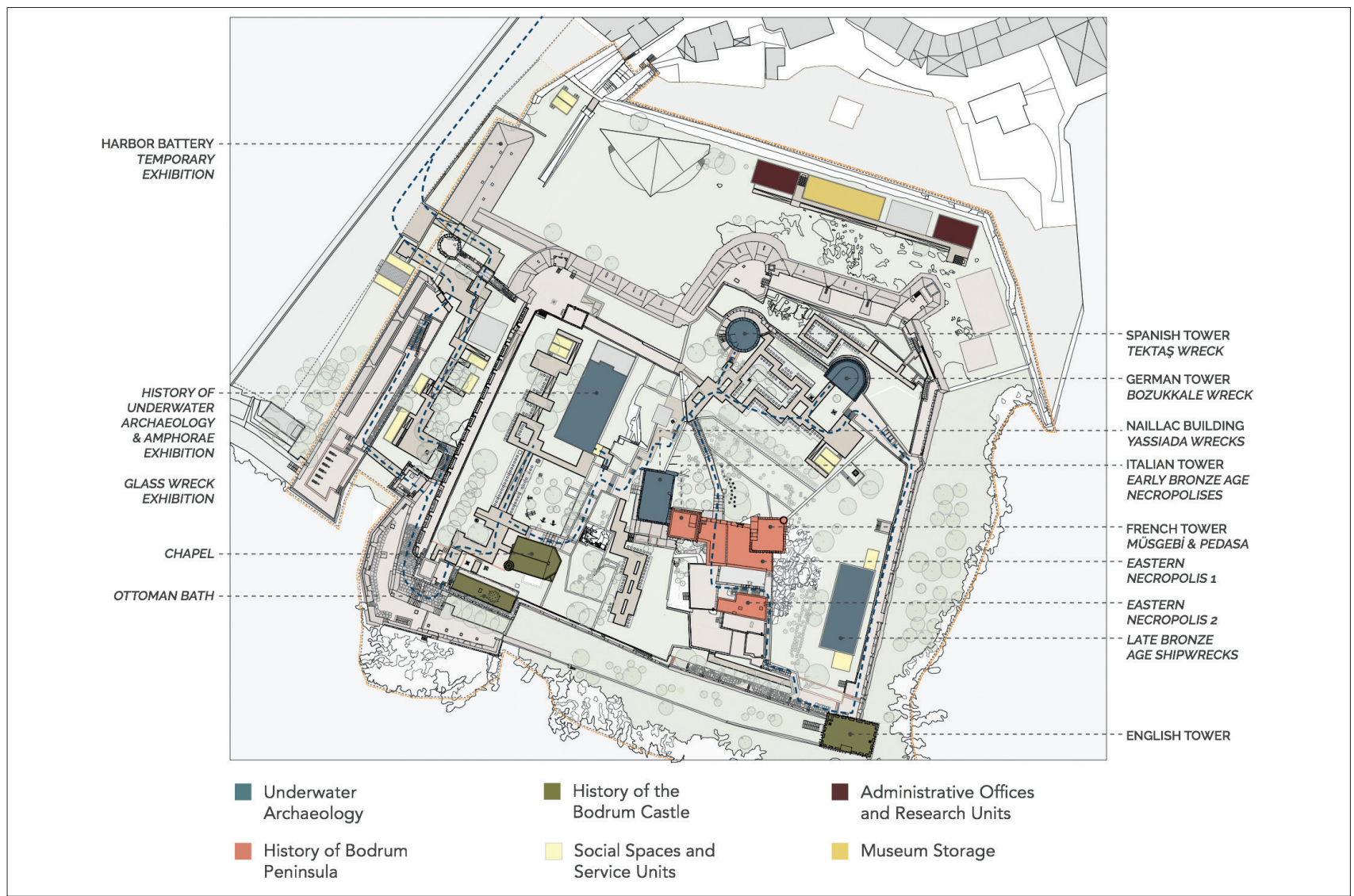

Figure 11: Proposed museum organization and circulation plan / Önerilen müze kurgusu ve dolaşım planı

(Fig.6) and conservation laboratories are collected under a single contemporary building that will suffice the climatic conditions and technical infrastructure for the conservation of artifacts. The offices and service spaces for the museum experts and staff have been provided within this proposal as well. All new building proposals have been distinguished from authentic castle parts by architectural formation and materials. They all have been distanced from castle walls to prevent any physical attachment and also slightly elevated from ground level to clearly reflect their condition as later additions within the Castle.

\section{RE-ORGANIZING THE BODRUM CASTLE AS A MUSEUM}

The process of re-designing the Bodrum Castle as a monumental building and as an underwater archaeology museum can be defined as navigating within a complex field where the trilogy of spaces-objects-narratives conceptually and visually has to be unified by negotiating historical data, digital models, architectural traces and museological demands. Following parts aim at demonstrating this field by cross-referencing themes, exhibitions and spaces in multiple scales of design.

\section{Defining Thematic Frameworks \& Order of Exhibitions}

Following the castle-scale conservation intervention decisions and spatial transformation strategies, museological studies have concentrated on constructing a framework that will distinguish multiple narratives on a continuous circulation before designing exhibitions. The historical, contextual and spatial narratives superimposed within the context of the Bodrum Castle are identified by three umbrella themes for displays:

1. History of the Bodrum Castle: Exhibitions of/ within the buildings/spaces distinguished in reflecting different historical periods of the Bodrum Castle by their architectural characteristics and/or authentic uses.

2. Underwater Archaeology: Exhibitions of the historical and methodological processes of underwater archeology along with the shipwrecks' collections in the museum.

3. History of the Bodrum Peninsula: Exhibitions presenting the geographical and historical character of the broader context that the Bodrum Castle is situated within. 
In reference to these three umbrella themes, the following studies on museology and display have been conducted:

- The artifacts in storage have been examined with museum experts and project coordinators in order to define possible collections to be displayed in the new museum organization.

- The relations between collections and possible exhibition spaces have determined by surveys, insitu research and series of meetings with museum experts.

- The inventory of all artifacts to be displayed has been compiled and a digital collection has been produced by three-dimensional modeling of all artifacts (Fig.12).

- The Bodrum Castle has been digitally modeled with the details of interior space formations.

- As a design approach, proposed modes of display have been completely modeled and tested in digital environment to achieve integrity between spaces - objects - narratives.

- While certain design principles, codes and elements have been defined for exhibiting artifacts within authentic spaces of the Castle, the individuality of visitors' experience in each "space - object narrative" superimposition is prioritized.

- A continuous yet episodic museum circulation has been configured to achieve a dynamic unity of thematic displays within the multi-layered context of the Bodrum Castle.
The integrity of exhibitions under each umbrella theme is sustained by a two-fold approach: (a) order of spaces and (b) types of display. The new organization of the museum can be outlined in reference to thematic frameworks and order of exhibitions as seen in Figures 11 \& 13.

\section{Unfolding Themes and Exhibition Approach}

\section{History of the Bodrum Castle}

The essential elements of display in this theme are the cultural properties distinguished in reflecting the history of the Bodrum Castle. In other words, the buildings and the spaces are the objects of display. The exhibitions are "building-oriented." By "displays of architecture" different episodes of Castle's history are narrated. There are no objects displayed in the exhibitions of "History of the Bodrum Castle." The spaces only consist of supportive textual and visual materials including old photographs and drawings depicting the Castle, short documentaries, animated videos and/or interactive interfaces.

To exemplify, the Chapel presents itself as a unique display where three different historical periods become physically observable within the context of a single building. While wall remnants of late antiquity exposed under the ground level, the previously plastered and painted interior of the upper structure is restored to reflect the Gothic architecture of the Chapel (Fig. 14). The exhibition brings the engravings of Newton into display, which depicts the building after its transformation into a

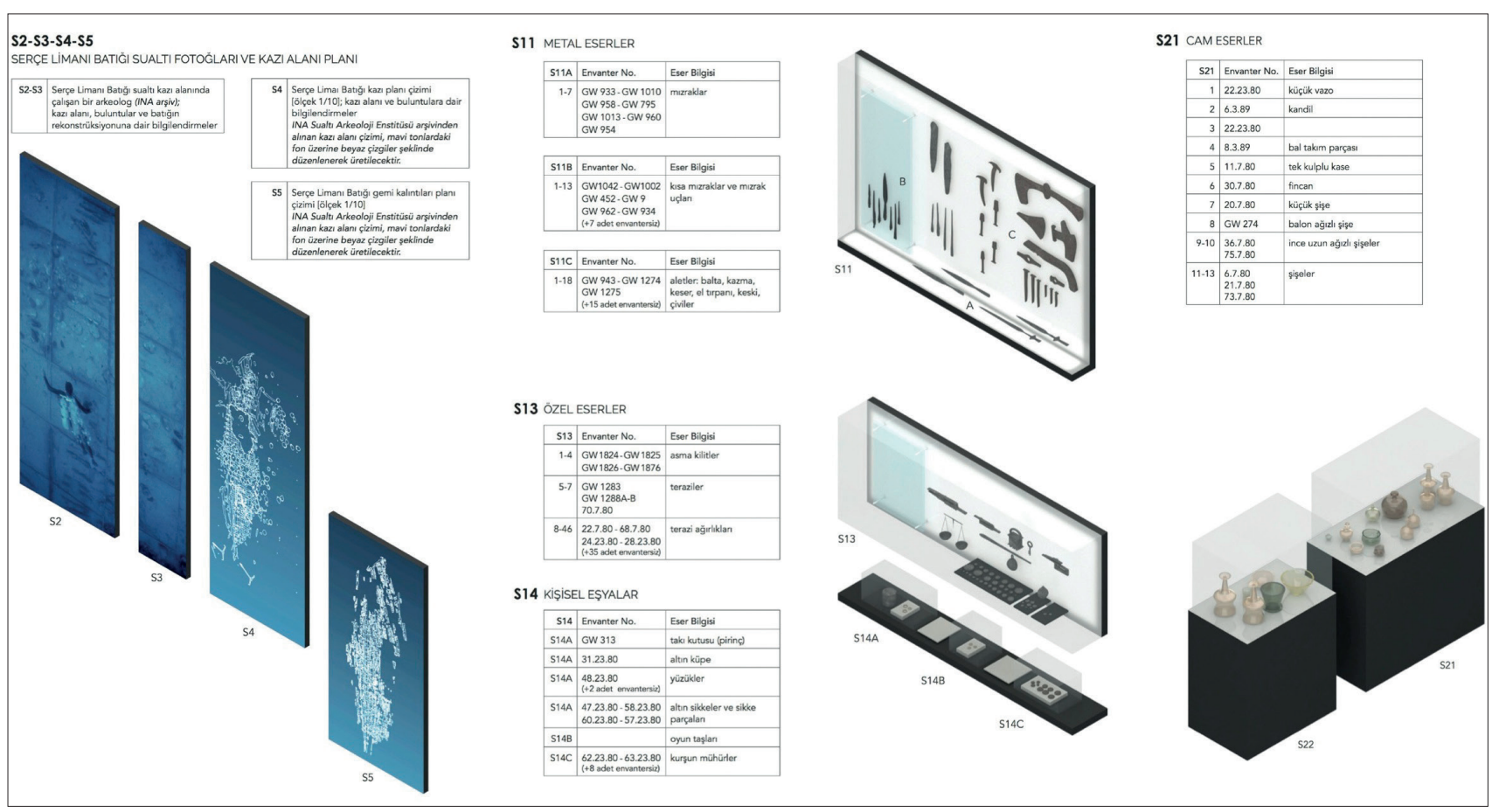

Figure 12: Examples from 3-dimensional models of artifacts to be displayed / Sergilenecek eserlerin 3-boyutlu modellerinden örnekler 


\begin{tabular}{|c|c|c|c|c|}
\hline Theme & Key Plan & Order of Spaces & Types of Display & Exhibitions \\
\hline $\begin{array}{l}\text { History of the } \\
\text { Bodrum Castle }\end{array}$ & & DISTRIBUTED & $\begin{array}{l}\text { BUILDING-ORIENTED } \\
\text { DISPLAYS of } \\
\text { ARCHITECTURE }\end{array}$ & $\begin{array}{l}\text { Chapel / Mosque (late antiquity + St.John } \\
\text { Knights period + Ottoman period) } \\
\text { Ottoman bath (Ottoman period) } \\
\text { English Tower (St.John Knights period) }\end{array}$ \\
\hline $\begin{array}{l}\text { Underwater } \\
\text { Archaeology }\end{array}$ & & SEQUENTIAL & $\begin{array}{l}\text { OBJECT-ORIENTED } \\
\text { (shipwreck-based) } \\
\text { DISPLAYS of TIME }\end{array}$ & $\begin{array}{l}\text { [11th century] Serçe Limanı } \\
\text { [7th century] Yassıada } \\
\text { [5th century] Yassıada } \\
\text { [5th century BCE] Tektaş } \\
\text { [6-7th century BCE] Bozukkale } \\
\text { [13th century BCE] Gelidonya } \\
\text { [14th century BCE] Uluburun } \\
\text { [16th century BCE] Şeytan Deresi }\end{array}$ \\
\hline $\begin{array}{l}\text { History of the } \\
\text { Bodrum Peninsula }\end{array}$ & & CLUSTERED & $\begin{array}{l}\text { CONTEXT-ORIENTED } \\
\text { DISPLAYS of CULTURE }\end{array}$ & $\begin{array}{l}\text { Early Bronze Age Nekropolises: } \\
\text { Kesik Servi, Çukurbük, Çingenalanı } \\
\text { Müsgebi Nekropolis } \\
\text { Eastern Nekropolis } \\
\text { Ancient City of Pedasa }\end{array}$ \\
\hline
\end{tabular}

Figure 13: Proposed museum organization in reference to exhibition themes, order of spaces and types of display / Sergi temaları, mekan düzeni ve sergileme tiplerine göre önerilen müze kurgusu
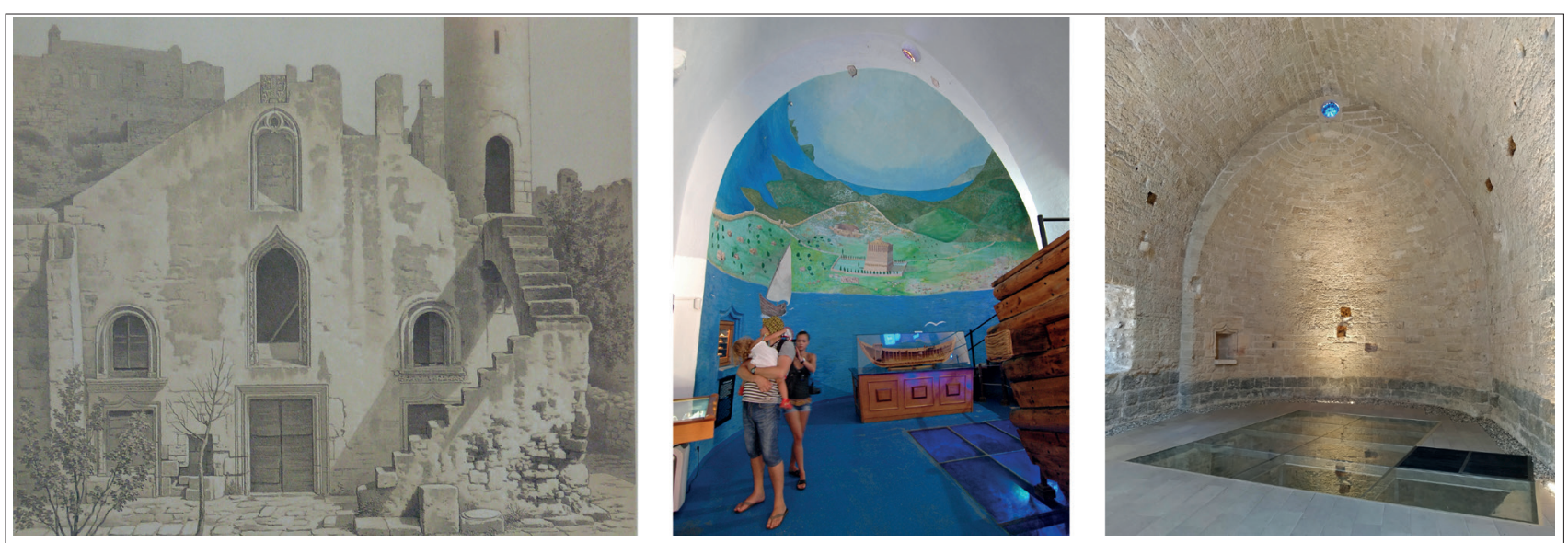

Figure 14: (left) Chapel / Mosque by Newton, 1862; (middle-right) Chapel / Mosque before and after restoration / (solda) Şapel / Kale Camisi, Newton, 1862; (ortada-sağda) Restorasyon öncesi ve sonrasında Şapel / Kale Camisi 
mosque in Ottoman period, to support the interpretation of the Chapel within the multi-layered context of the Castle by superimposing narratives of architecture and history in the same space.

As the exhibitions are building-oriented, the theme is "distributed" throughout the Castle in reference to the buildings interpreted within this theme. Even though three buildings - the Chapel, Ottoman Bath and the English Tower - are distinguished and accommodated by supportive exhibitions within the theme of Castle History, all defensive walls, structures as well as moats and baileys should be considered as part of this theme.

\section{Underwater Archaeology}

Underwater archaeology exhibitions are mainly composed of shipwreck collections. Even though underwater archaeology exhibitions are collectively identified as a thematic section within the museum, the exhibitions are "object-oriented." Since shipwrecks are assessed as "time capsules" within the discipline of underwater archaeology, the integrity of a shipwreck collection with all artifacts found on the shipwreck is essential in conservation and display. Therefore, while each exhibition within the theme of underwater archaeology is shipwreck-based, the order of exhibitions is defined to be "sequential." As each shipwreck collection can be assessed as a display of a particular section extracted from the continuity of time, the sequential totality of shipwreck collections frame a more comprehensive understanding in terms of the developments in shipbuilding techniques, changes in the trade routes, daily practices, advancements in technology and so on.

In reference to their locations in the Castle and to the dates of the ships, beginning and end of underwater archaeology exhibitions are determined by two large shipwreck collections - the Serçe Limanı Shipwreck $\left(11^{\text {th }}\right.$ century CE) and the Late Bronze Age Shipwrecks the centerpiece of which is the Uluburun Shipwreck (14 $4^{\text {th }}$ century BCE) collection. As these two shipwrecks define two extremes within the chronology of shipwrecks in the museum collection, the other shipwreck exhibitions are aligned in-between. However, the order of exhibitions employs a reverse chronology - beginning with an $11^{\text {th }}$ century shipwreck and going back in history until $16^{\text {th }}$ century BCE. This reverse chronology was also necessitated by the immovable reconstruction of Serçe Limanı, the structural framework of which was anchored to the foundations of the later addition built in 1983 and thus the re-assembled hull has to be conserved in-situ ${ }^{11}$. Since Serçe Limanı Shipwreck, and the later

$\overline{11}$ In February 2015, the possibilities for strengthening and addition built to accommodate the re-assembled hull of the ship (Matthews 1983; Bass, Matthews, Steffy, and Van Doorninck 2004; Steffy 2012), is the first underwater archaeology exhibition to be visited in the Castle, the building is transformed to accommodate an introductory exhibition on underwater archaeology, its disciplinary formation and methods and the united histories of the Castle and underwater archaeology. This introductory exhibition also used as an opportunity to present a preview of the museum's underwater archaeology collection by associative and contextual mappings of the shipwrecks and their underwater excavation processes (Fig.15).

Within the scope of museological research, the fundamental source of reference was the Institute of Nautical Archaeology (INA) ${ }^{12}$ founded by Dr. George F. Bass in 1972. By studying into archives and libraries of INA both in Bodrum Research Center and in United States, all shipwreck collections have been organized by cross-referencing the artifacts with the visual and textual data produced during and after underwater excavations (Fig.16). In order to provide a legible system to be followed by visitors, a consistent framework that will regulate the contents and displays in all shipwreck exhibitions is defined to unfold and interpret the shipwreck in different levels by defining the shipwreck as an archaeological finding; by studying the shipwreck through the process of underwater excavation; and by understanding shipwreck as a historic vessel.

As research on shipwrecks is still in progress, the exhibitions are not limited by a re-design of existing artifact displays but rather to present up-to-date discoveries by digital models, animations as well as revised reconstructions ${ }^{13}$. Since museums display objects as abstracted from their context - and in the case of underwater archaeology the distance of abstraction is quite dramatic - a referential display strategy is proposed for underwater archaeology

moving the structural framework of the res-assembled hull of Serçe Limanı shipwreck were examined by in-situ surveys and meetings with the participations of Robin Piercy, INA expert who worked in the re-assembly process of the hull, and INA Bodrum Research Centre director Tuba Ekmekçi. Based on insitu observations and discussions and the report on Serçe Limanı written by Piercy, it is decided to conserve the re-assembled hull in-situ and the processes of renovation planned accordingly.

2 See, https://nauticalarch.org/ (Last accessed: 15/11/2021).

13 1:1 scale reconstruction model of the Uluburun wreck has been produced by the consultancies of Cemal Pulak and INA specialists. For more information on the significance of the Uluburun wreck see, Cemal Pulak, "The Uluburun Shipwreck and the Late Bronze Age Trade," Beyond Babylon: Art, Trade, and Diplomacy in the second millennium $B C$, New York: Metropolitan Museum of Art, 2008: pp. 289-310. 
RE-INTERPRETING THE BODRUM CASTLE UNDERWATER ARCHAEOLOGY MUSEUM

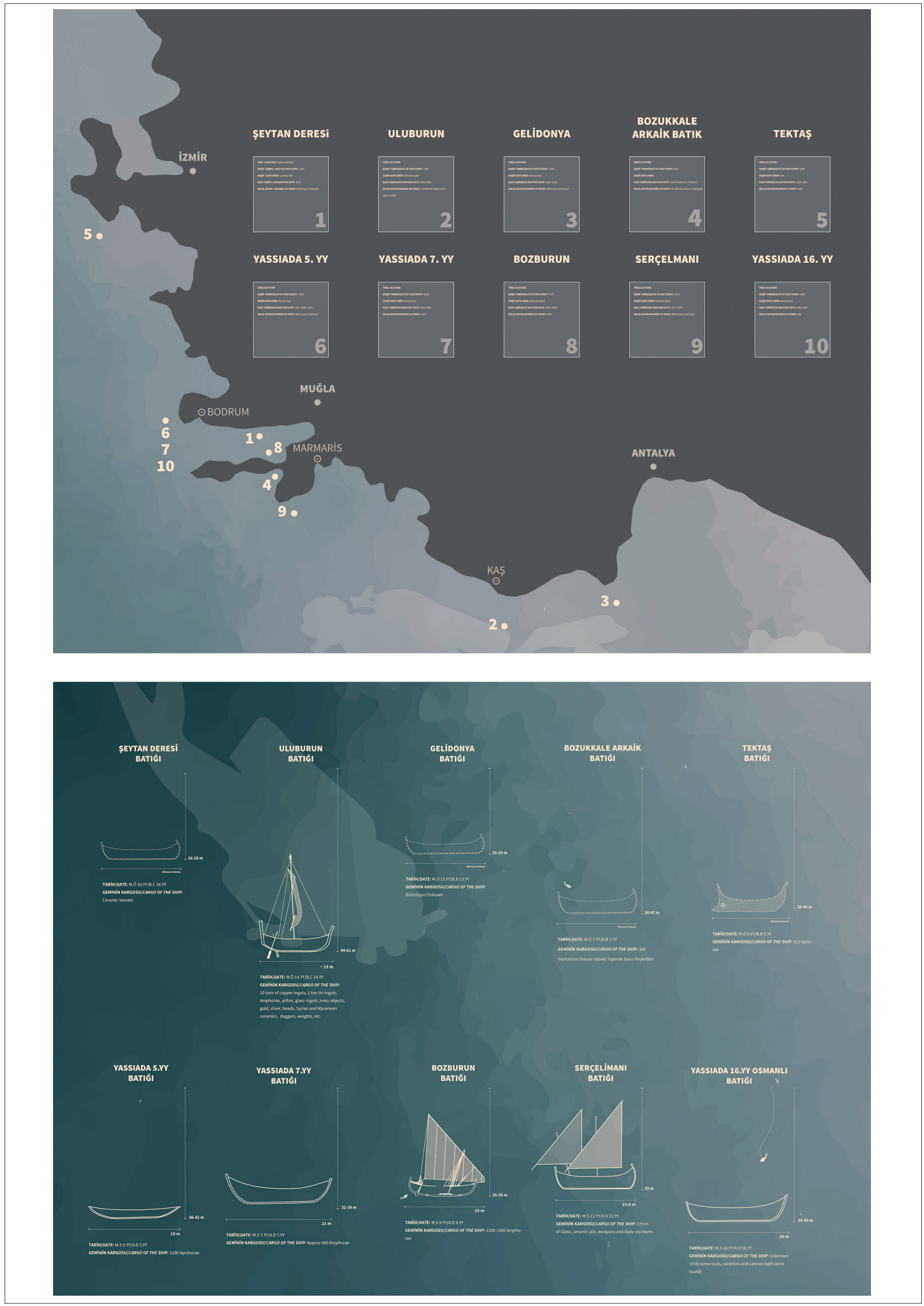

Figure 15: Comparative mappings of the shipwrecks in museum collection / Müze koleksiyonunda yer alan batıkların karşılaştırmalı haritalamast 


\begin{tabular}{|c|c|c|c|c|c|c|c|}
\hline & Seytan Deresi & Uluburun & Gelidonya & Tektas & Yassiada 7.yy & Bozburun & Sercelimani \\
\hline date & MO 16.yy? & Mo 14.yy & MO 13.yy & MO 5.yy & MS 7.yy (MS 625-626) & MS 9.yy & MS 11.yy (MS 1025) \\
\hline $\begin{array}{l}\text { dimensions of hull } \\
\text { (length/width) }\end{array}$ & Bilinmiyor/Unkown & approx $15 \mathrm{~m}$ & & & $21 \mathrm{~m}$ & $15 \mathrm{~m}$ & $15.6 \mathrm{~m}$ \\
\hline $\begin{array}{l}\text { cargo (different load } \\
\text { types - primary load, } \\
\text { secondary load) }\end{array}$ & Ceramic vessels & $\begin{array}{l}10 \text { tons of copper ingots, } 1 \text { ton tin } \\
\text { ingots, Amphorae, pithoi, glass ingots, } \\
\text { ivory objects, gold, silver, beads, Syrian } \\
\text { and Mycenean ceramics, daggers, } \\
\text { weights, etc. etc. }\end{array}$ & & 213 aphorae & Approx 900 Amphorae & 1200-1500 amphorae & $\begin{array}{c}3 \text { tons of Glass, ceramic } \\
\text { jars, weapons and daily } \\
\text { use items }\end{array}$ \\
\hline route (or possible routes) & Local? & From Cenaan lands to the west & From Levant to west & & & & $\begin{array}{l}\text { From Syria to } \\
\text { Constantinopole }\end{array}$ \\
\hline EXCAVATION & & & & & & & \\
\hline $\begin{array}{l}\text { date of discovery and by } \\
\text { whom }\end{array}$ & $\begin{array}{c}\text { Found in } 1965 \text { by } \\
\text { Cumhur llik (sponge } \\
\text { diver) }\end{array}$ & $\begin{array}{l}\text { Found in } 1982 \text { by Mehmet Cakir } \\
\text { (sponge diver) }\end{array}$ & $\begin{array}{c}\text { Found in } 1954 \text { by Kemal } \\
\text { Aras (sponge diver) }\end{array}$ & Found in 1996 by INA & $\begin{array}{c}\text { Found in } 1958 \text { by Kemal } \\
\text { Aras }\end{array}$ & $\begin{array}{l}\text { Found in } 1973 \text { by } \\
\text { Mehmet Askin }\end{array}$ & $\begin{array}{c}\text { Found in } 1973 \text { by } \\
\text { Mehmet Askin (sponge } \\
\text { diver) }\end{array}$ \\
\hline excavation dates (years) & 1975 & 1984-1994 & $1960-2010$ & 1999-2001 & $1961-1964$ & $\begin{array}{c}\text { Surveyed } 1982 \text { and } \\
\text { excavated in 1995-1998 }\end{array}$ & 1977-1979 \\
\hline $\begin{array}{l}\text { duration (how many } \\
\text { seasons of excavation?) }\end{array}$ & 1 & 11 & 2 & 3 & 5 & 4 & 3 \\
\hline $\begin{array}{l}\text { depth of the excavation } \\
\text { site (depth of the found } \\
\text { wreck) }\end{array}$ & $33 \mathrm{~m}$ & $44-61 \mathrm{~m}$ & $26-28 \mathrm{~m}$ & $38-45 \mathrm{~m}$ & $32-39 \mathrm{~m}$ & $30-35 \mathrm{~m}$ & $33 \mathrm{~m}$ \\
\hline $\begin{array}{l}\text { dimensions of the } \\
\text { excavation site }\end{array}$ & $\begin{array}{l}\text { Scattered objectsin } 42 \\
\text { m2 area }\end{array}$ & & & & & $20 \times 8 \mathrm{~m}$ & \\
\hline number of dives & & more than 22.400 & & 5046 & & 2189 & \\
\hline $\begin{array}{l}\text { findings (types, numbers, } \\
\text { etc.) }\end{array}$ & $\begin{array}{l}\text { Pithoi, craters and } \\
\text { ceramic jars }\end{array}$ & & & $\begin{array}{c}\text { amphorae, ceraamic } \\
\text { jars, lead anchor stocks, } \\
\text { ophtalmoi }\end{array}$ & & & \\
\hline CONSERVATION & & & & & & & \\
\hline \begin{tabular}{|l} 
period of conservation \\
(i.e. 1984-2002)
\end{tabular} & $\begin{array}{l}1975-1980 \text { but still the } \\
\text { objects are under the } \\
\text { control of INA } \\
\text { conservators } \\
\text { periodically }\end{array}$ & 1984-2015 still under work & $\begin{array}{l}\text { Took years and still 2010 } \\
\text { findings are under work }\end{array}$ & $\begin{array}{l}\text { Lots of them finished } \\
\text { but still underwork }\end{array}$ & $\begin{array}{l}\text { Conservation is finished } \\
\text { in } 10 \text { years but study } \\
\text { still continues }\end{array}$ & $\begin{array}{c}\text { Most of the } \\
\text { conservation finished in } \\
16 \text { years }\end{array}$ & $\begin{array}{l}\text { Finished in } 10-12 \text { years, } \\
\text { study still continues }\end{array}$ \\
\hline
\end{tabular}

Figure 16: Shipwrecks data chart / Batıklar veri çizelgesi 
exhibitions. Artifacts are not only accompanied by historical information or graphics that narrate their authentic purposes but displayed along with photographs, videos or drawings from underwater excavations so that visitors will be able to situate the object with excavation and conservation processes by associating the artifact to its multiple histories.

\section{History of the Bodrum Peninsula}

This theme is composed of "context-oriented" exhibitions displaying archaeological collections from necropolises and ancient cities within the Bodrum Peninsula. The exhibitions are "context-based" to provide insights about the cultures, traditions and narratives of different civilizations inhabited this geography. This thematic section is located at the highest location of the Castle, which is predominantly identified by the French and Italian Towers. Exhibitions are "clustered" within the group of spaces defined within the French and Italian Towers as well as cultural properties built around these closely situated towers. With this strategic clustering of exhibitions at the highest location of the Castle, visitors' association with the context is augmented by the panoramic views of the peninsula experienced on the terraces defined by the group of buildings.

\section{Developing Strategies of Display and Designing Exhibitions}

Depending on the authenticity of spaces, two major strategies are developed for exhibition design. For "castle spaces" that will be transformed into "exhibition spaces," the space is expressed as part of the display. In other words, a space defined within a cultural property displays itself as a "castle space" along with the artifact collection to be displayed within that specific space. On the hand, the spaces defined within later additions are assessed as recessive in reference to the collection. The spatial transformations and interventions are applied in such a way that the space will remain as an "envelope" for the exhibition.

The strategy for "space as part of display" is articulated as followed:

- The aim is to emphasize the space as an "object of display" as well. The modernist approach to render exhibition spaces as neutral blank environments in order to focus on the objects of display is rejected. ${ }^{14}$

\footnotetext{
14 The purist approach to exhibition space under the influence of modernist movement emerged in the early twentieth century. The exhibition space was flattened and abstracted from context and time by clinical white walls. White walls also rendered space indifferent to its content as they emphasized the extraction of the
}

Consistent with building-scale conservation interventions, all interior surfaces of thick castle walls are scraped and left exposed.

- New floors upon which display elements attached are recessed from medieval castle walls and thus strengthening walls' architectural expression by rendering them independent from the display.

- All display elements are detached and distanced from the boundaries of spaces.

- By positioning display elements towards the center of spaces, the exhibition circulation is pushed to the periphery of space and thus the visitor is deliberately situated in-between space and display.

- A consistent and plain visual quality is embraced in the design of exhibitions to reduce the tension between architectural expression of spaces and clarity of artifacts in display.

- Hybrid modes of lighting (object lighting + ambience lighting) are utilized to achieve dim environments where spaces and objects can be perceived together.

Above-mentioned design principles (Fig.17) and display strategies are applied in spaces defined within cultural properties in reference to interior space formations and proportions and the object collections to be displayed. Considering the exhibition themes and castle-scale order of spaces in museum circulation, there occurred multiple superimpositions of spaces, objects and themes. Varying applications of these design principles in different superimposed contexts can be seen in Figure 18 consisting of, respectively, the plans of the Naillac building and German Tower designed to display two different shipwreck collections among underwater archaeology exhibitions and the space in the upper level of the French Tower which was previously used as a storage and now accommodating an exhibition under the history of Bodrum Peninsula theme. Besides these three examples provided, the transformation of castle spaces that are designed with exhibitions and the balance intended between displays and spaces can be seen in Figures 19 \& 20.

\footnotetext{
object from its original environment and sustained its status as a museum object. Exhibition space was identified as a "white cube," which provided an infinite, flexible, transformable and if necessary divisible volume. For more on the "white cube" phenomenon see, Brian O'Doherty, Inside the White Cube: The Ideology of the Gallery Space, San Francisco: The Lapis Press, 1986.
} 


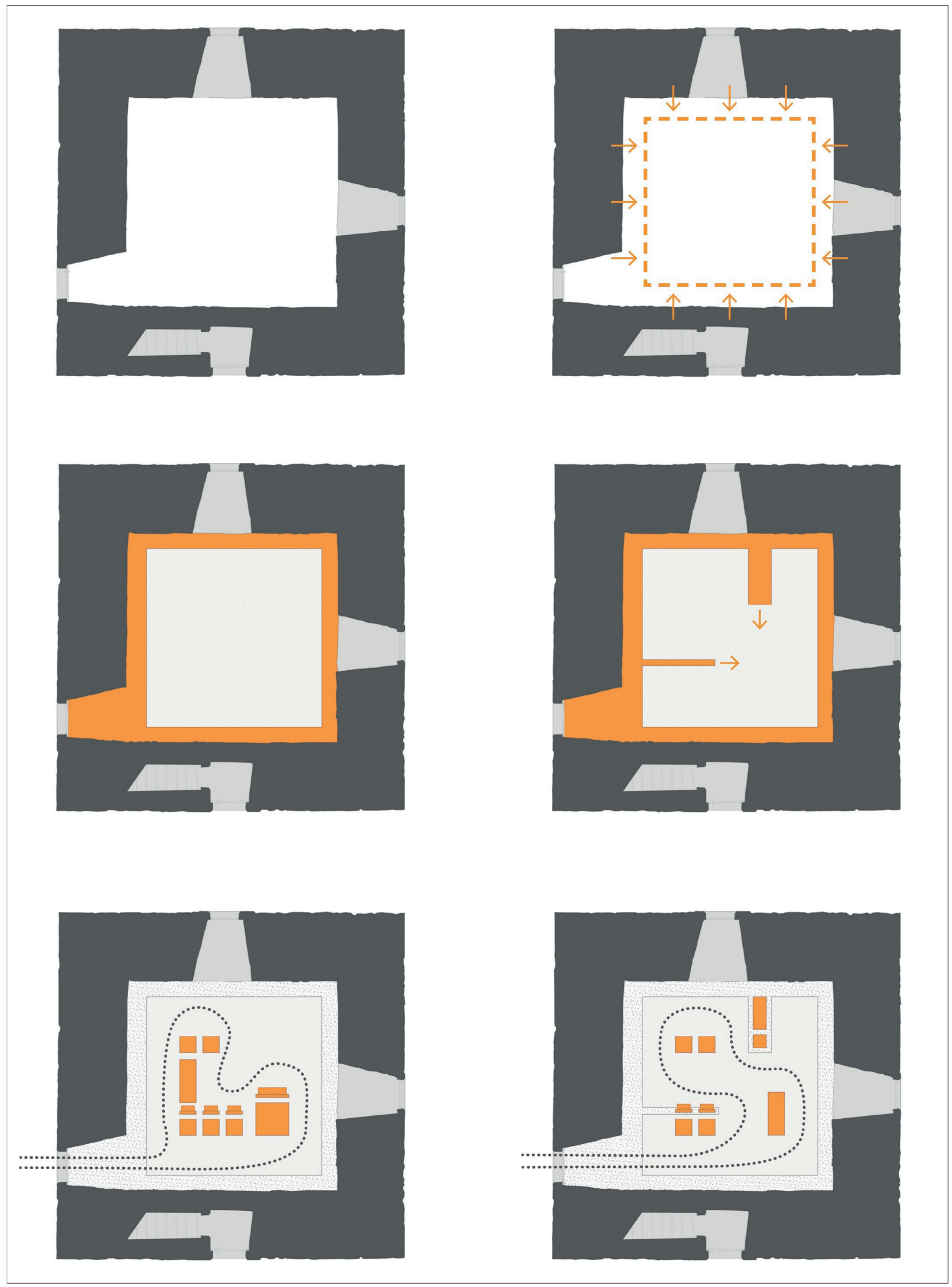

Figure 17: Exhibition design principles for castle spaces defined within cultural properties / Kültür varlı̆̆ı niteliğindeki kale mekanlarında sergi tasartm prensipleri 


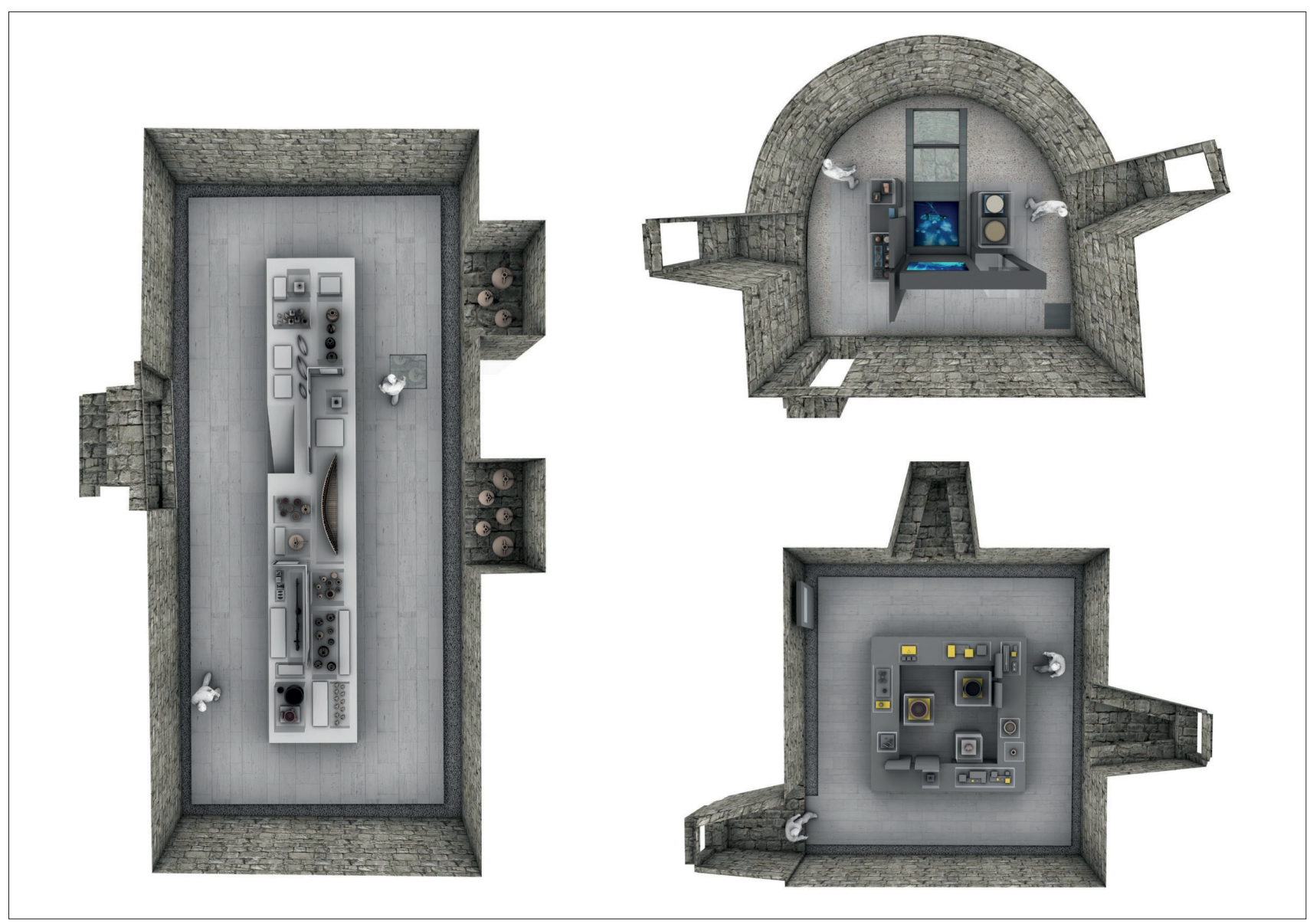

Figure 18: Varying applications of design principles in different cultural properties: (left) the Naillac building \& Yassiada shipwrecks exhibition; (top-right) the German Tower \& Bozukkale wreck exhibition; (bottom-right) the French Tower \& ancient city of Pedasa exhibition / Sergi tasarım prensiplerinin kültür varlı̆̆ı niteliğindeki yapılarda çeşitlenen uygulamaları: (solda) Naillac yapısı \& Yassıada batıkları sergisi; (să̆-üstte) Alman Kulesi \& Bozukkale batı̆̆ sergisi; (să̆-altta) Fransız Kulesi \& Pedasa antik kenti sergisi

Diverging from the first, the strategy for "space as envelope" articulated by transformations in larger scale regarding the expanded scope of interventions in later additions (Fig.20). This strategy is employed in two buildings displaying the shipwreck collections that define the beginning and the end of underwater archaeology exhibitions - the Serçe Limanı Shipwreck (Fig.21-23) and Late Bronze Age Shipwrecks exhibitions (Fig.24-25). The strategy for re-designing later additions as exhibition spaces develops by following courses:

- The space is treated as a dark background for a more dramatic concentration on the collection.

- The boundaries of the space are utilized and/ or articulated as primary exhibition surfaces to display artifacts as well as to reflect the ambience of underwater by large-scale images, projections and models.

- Previous order of spaces followed as room-byroom exhibitions in both buildings is abandoned by removing separation walls. The interior spaces are transformed into holistic exhibition volumes uniting different objects and modes of display.

- By displaying artifacts and centerpieces of exhibitions - regarding the scale and the position of the re-assembled hull of Serçe Limanı wreck and 1:1 scale re-modeling of the Uluburun wreck - in the same volume, associations between the objects and the vessels they have transported within are amplified.

- Accesses to buildings are re-designed according to castle-scale circulation scheme and circulation zones within buildings are re-organized and expanded. 


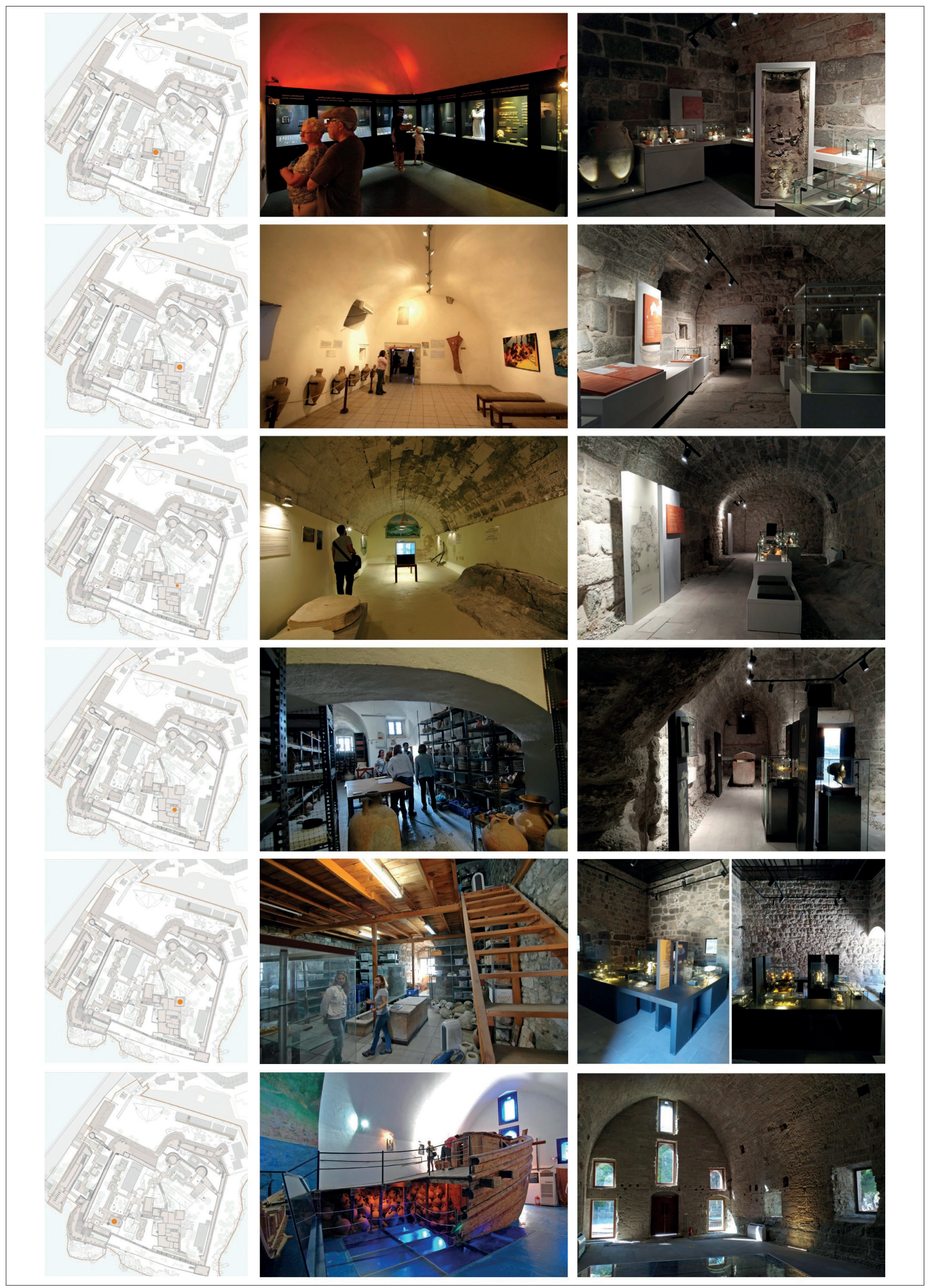

Figure 19: Spatial transformation of cultural properties by history of the Bodrum Castle and history of Bodrum Peninsula exhibitions / Kültür varlı̆̆ niteliğindeki yapıların Kale Tarihi ve Bodrum Yarımadası Tarihi sergileriyle mekansal dönüşümü 
RE-INTERPRETING THE BODRUM CASTLE UNDERWATER ARCHAEOLOGY MUSEUM

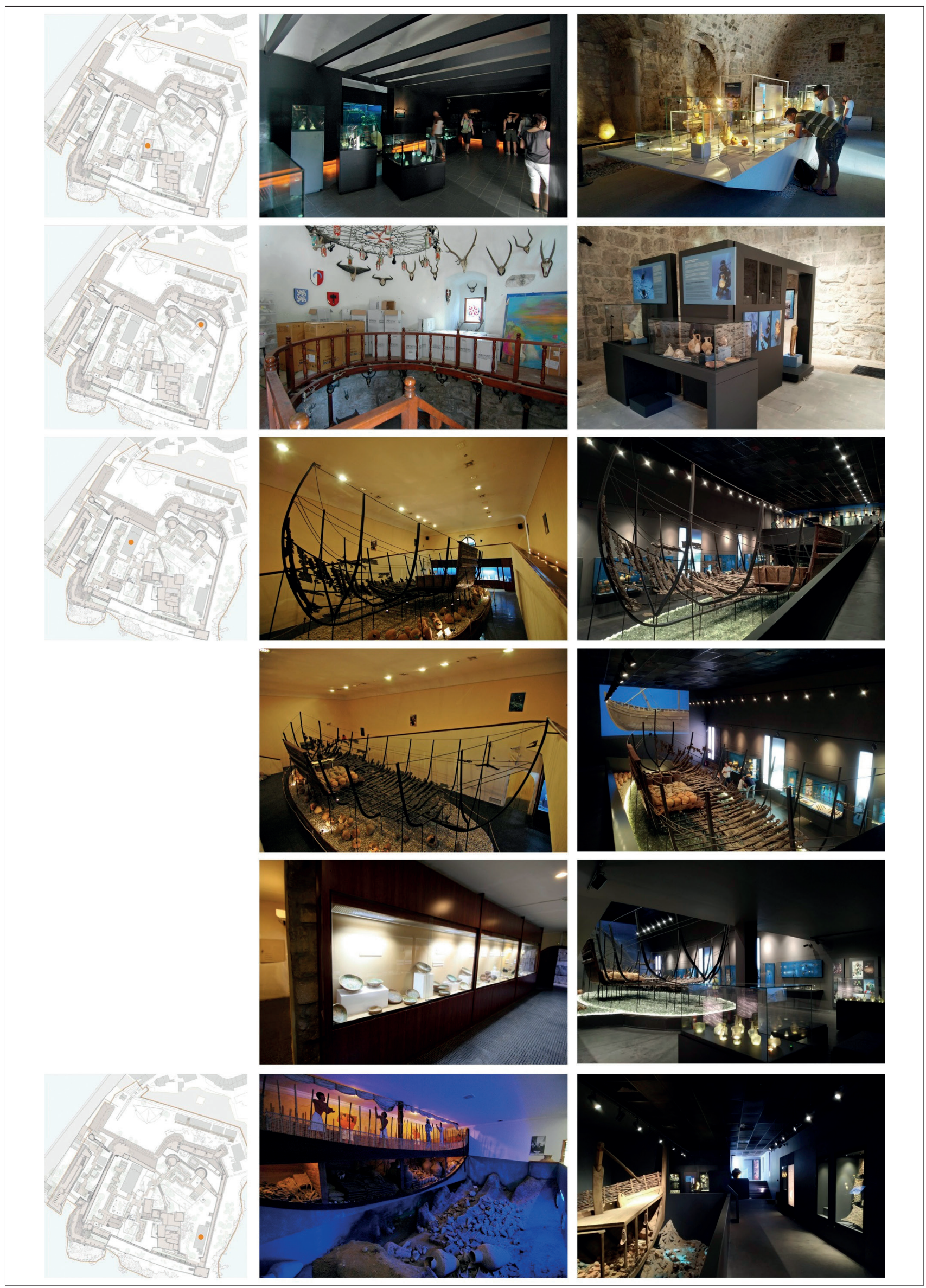

Figure 20: Spatial transformation of cultural properties and later additions by Underwater Archaeology exhibitions / Kültür varlı̆̆ niteliğindeki yapılar ve geç dönem eklerinin Sualtı Arkeoloji sergileriyle mekansal dönüşümü 


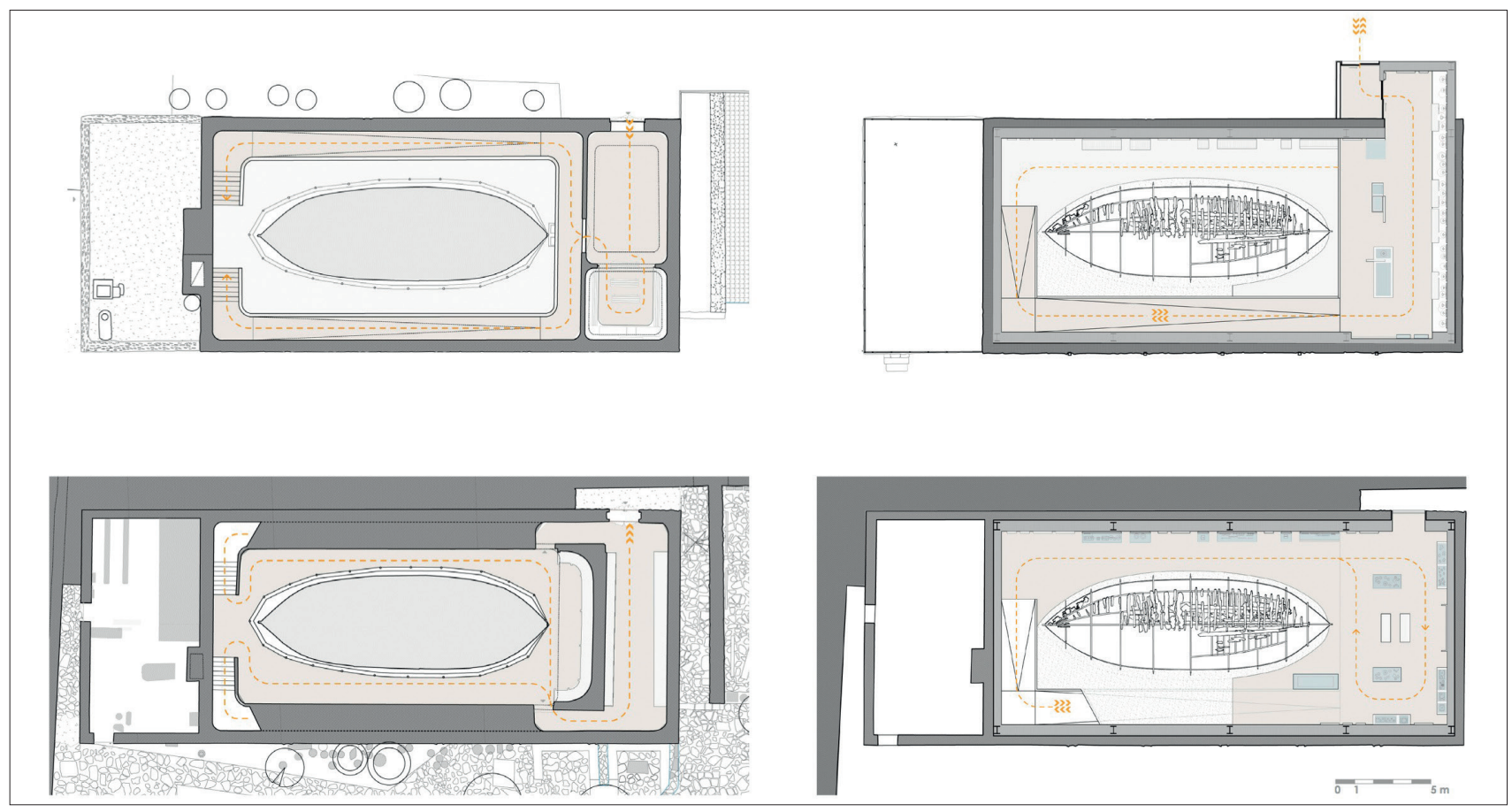

Figure 21: Serçe Limanı “Glass Wreck” exhibition plans before (left) - after (right) / Serçe Limanı "Cam Batığı” sergisi planları öncesi (solda) - sonra (sağda)

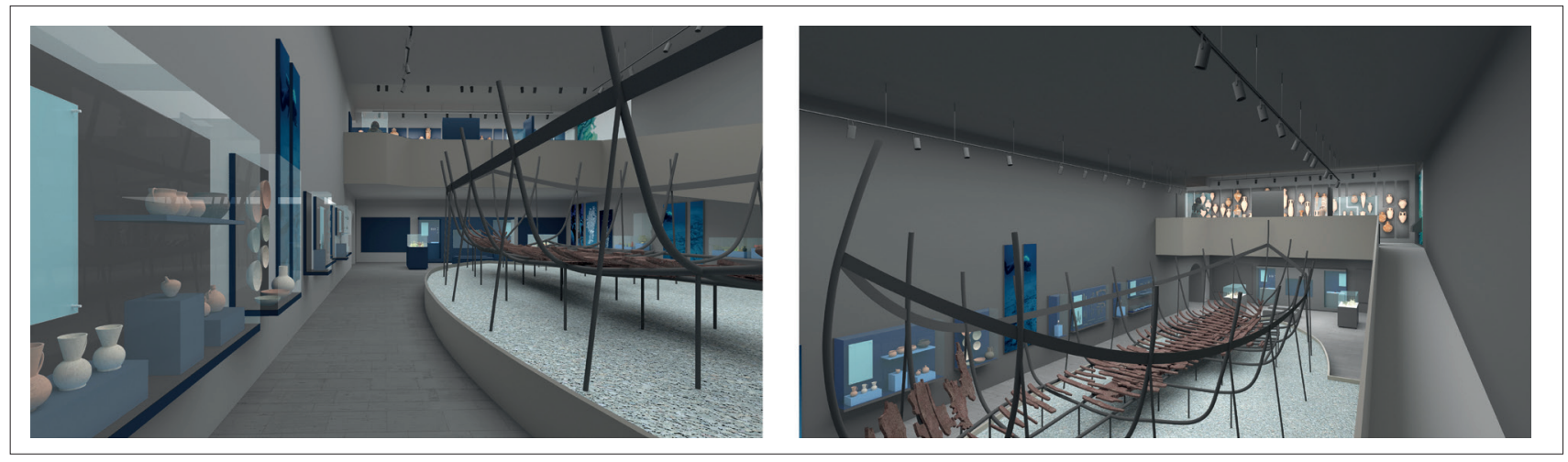

Figure 22: Serçe Limanı "Glass Wreck” exhibition design proposal / Serçe Limanı "Cam Batı̆̆ l” sergi tasarımı önerisi
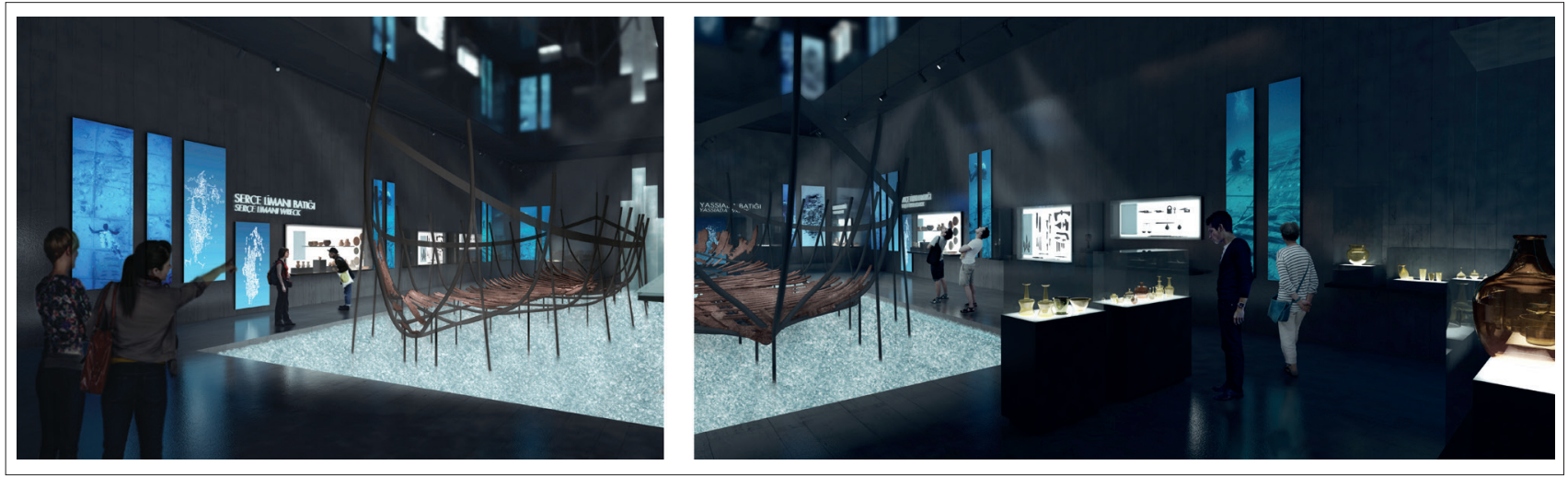

Figure 23: Serçe Limanı "Glass Wreck” exhibition proposal renders / Serçe Limanı “Cam Batığı” sergisi görselleri 


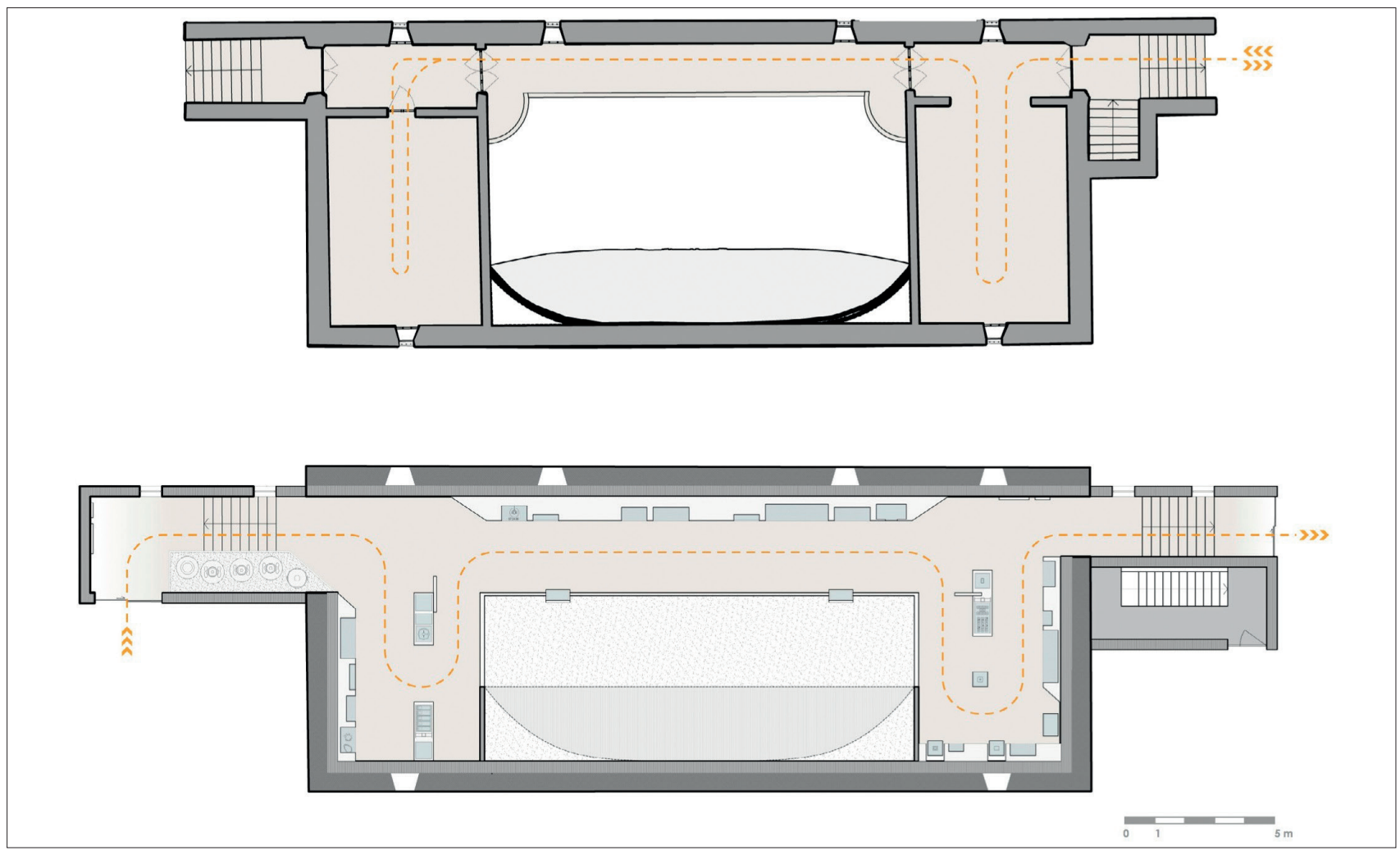

Figure 24: Late bronze age shipwrecks exhibition plans before (top) - after (bottom) / Geç bronz çağı batıkları sergi planları önce (üstte) - sonra (altta)
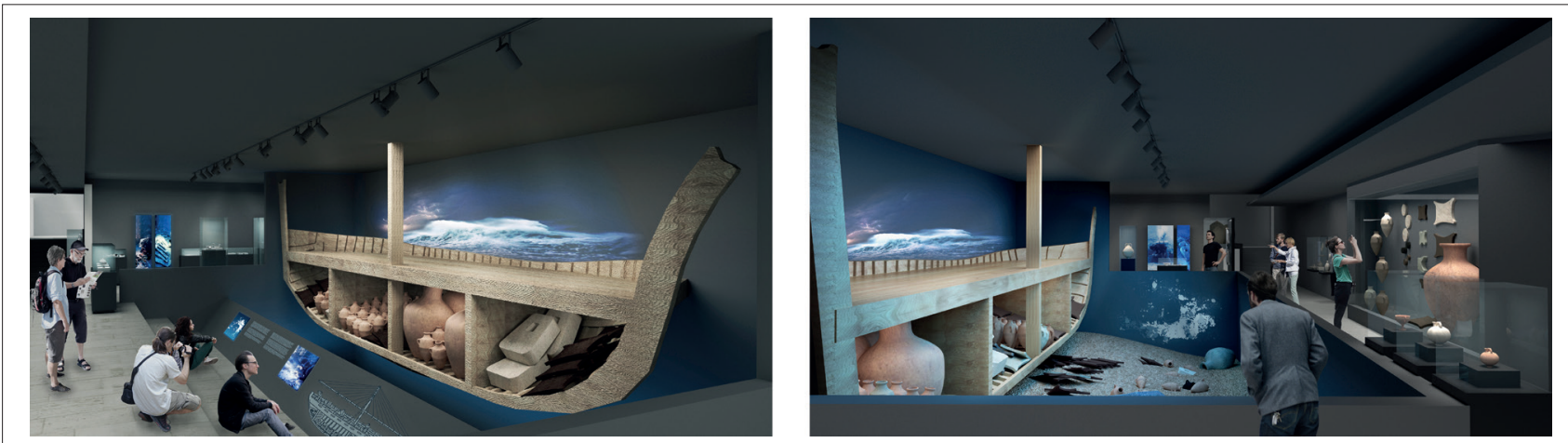

Figure 25: Uluburun shipwreck exhibition proposal renders / Uluburun batı̆ğ sergi önerisi görselleri

\section{CONCLUSION}

The analyses, observations, assessments and finally design proposals developed as part of the architectural conservation project of the Bodrum Castle from 2014 through 2016 necessitated an adaptive methodology for conducting research, restoration and design studies coherently. "Exhibition and display design" was not reduced to an interior design problem or a display case arrangement, which is to be developed after completion of restoration. Re-interpretation of the Bodrum Castle as a monumental building, as a heritage site, and as an underwater archaeology museum is approached as an interdisciplinary problem of conservation and design. In Turkey, processes of conservation and exhibition design are conducted separately. When this separation is necessitated by separate project contracts, restoration project, and occasionally restoration implementation, is completed and then exhibition design project is developed building upon the intervention decisions or completed restoration. When restoration and exhibition design are defined under the same project, the common approach is to postpone the design process until the beginning of restoration phase. In both situations, the communication between conservation and design teams is reduced to minimum. It is possible to claim that many projects and implementations are completed with missed opportunities in expanding the scope of research studies and sharing discovered materials and information from multiple disciplinary fields, discussing and assessing problems and potentials 
from different perspectives, developing comprehensive intervention decisions, achieving interconnected infrastructure and design solutions, adapting to emerging conditions and so on. Considering the case of the Bodrum Castle, it is explicit that how all intervention decisions, including conservation, engineering and design, must be integrated. Even though this study demonstrates this integrated methodology over spatial transformation and exhibition design strategies, the necessity of expanding the scale of integration between multiple disciplines and projects can be immediately visualized when museum circulation within the Castle is understood as inherent to landscape design.

The primary aim to make the Bodrum Castle and the museum collection visible and interpretable in reference to historical, contextual, architectural and spatial superimpositions was pursued by developing design strategies in general and by the consistent articulation of these strategies for each space in particular. Between 2018 and 2021, consistent with the strategies and principles employed in exhibition and display design project, exhibition implementations have been revised by series of as-built drawings ${ }^{15}$ in case of necessities emerged during restoration and implementation process. The challenges in the process of correlating restoration and design resulted in a comprehensive and reciprocal framework for spatial transformation and architectural intervention decisions for both fields. The case of the Bodrum Castle Underwater Archaeology Museum presents a reference for future studies in confronting contemporary challenges of transforming monumental buildings in multi-layered contexts into museums.

\footnotetext{
15 As-built drawings are revised set of drawings that record modifications in the original project in different levels of scale. Original design projects can be modified depending on the emerging conditions during construction or implementation. In conservation projects, as-built surveys are also produced to document interim phases during restoration process as well as final restored conditions in order to acquire accurate base drawings for developing precise solutions and/or revisions while producing as-built projects.
} 


\section{REFERENCES}

All figures are produced and/or photographed by the authors unless specified otherwise.

AYKAÇ, P. 2017.

Musealisation as an Urban Process: The Transformation of Sultanahmet District in Istanbul's Historic Peninsula. Unpublished Ph.D. Dissertation, UCL Bartlett School of Architecture, London.

BASS, G. F. 1996.

Shipwrecks in the Bodrum Museum of Underwater Archaeology, Ankara: Dönmez Offset.

BASS, G. F. 2005.

Beneath the Seven Seas, London: Thames \& Hudson.

BASS, G. F. 2012.

Archaeologist Beneath the Sea, İstanbul: Boyut Publishing.

BASS, G. F., MATTHEWS, S. D., STEFFY, J. R., and VAN DOORNINCK, F. H. 2004.

Serçe Limanı: An Eleventh-Century Shipwreck, vol. 1, Texas A\&M University Press.

BAYKARA, T. 1992.

"Bodrum," Türkiye Diyanet Vakfi İslam Ansiklopedisi, Vol. 6, İstanbul, 247-249.

BİLGİN ALTINÖZ, A.G., ŞAHİN GÜÇHAN, N., AYHAN, N., BAKIRER, Ö. 2011.

"An Introduction to Processes and Terminology on the Conservation Of Cultural Properties in Turkey," International Conference on Seismic Protection of Cultural Heritage, Antalya.

BİLGIN ALTINÖZ, A.G. 2002.

Assessment of historical stratification in multilayered towns as a support for conservation decision-making process; a Geographic Information Systems (GIS) based approach case study: Bergama. Unpuslished Ph.D. Thesis, Faculty of Architecture, METU, Ankara.

DESVALLÉES, A. and F. MAIRESSE (Eds), 2010.

Key Concepts of Museology, ICOM International Councils of Museums and Museé Royal de Mariemont, Paris: Armand Colin.

DİLER, A. 2007.

Muğla Kültür Envanteri, I, Bodrum Kentsel Sit Halikarnassos, Muğla Üniversitesi, Karya Araştırma ve Uygulama Merkezi, Muğla Valiliği İl Özel İdaresi Yayınları, Muğla.

EVLIYYA ÇELEBİ. 2005 .

Seyahatnâme, book IX [1671], (Yücel Dağl1, Seyit Ali Kahraman, Robert Dankoff Eds.), İstanbul: Yap1 Kredi Yayınları.

GALANTİ, A. 1945.

Bodrum Tarihi, İstanbul: Işık Press.

KALÇAS, E.L. 1989.

Bodrum Castle and Its Knights, İzmir: Bilgehan Press.

KIRSHENBATT-GIMBLETT, B. 1998.

Destination Culture: Tourism, Museums, and Heritage, Berkeley: University of California Press.

MATTHEWS, S. D. 1983.

The Rig of the Eleventh-Century Ship at Serçe Limanı, Turkey, Unpublished Masters Thesis, Graduate College of Texas A\&M University.

NEWTON, C. T. 1862.

A History of Discoveries at Halicarnassus, Cnidus and Branchidae, London: Day\&Son.

O’DOHERTY, B. 1986.

Inside the White Cube: The Ideology of the Gallery Space, San Francisco: The Lapis Pres.

PEDERSEN, P. 2004.

“Halikarnassos 2002," 25. Kazı Sonuçları Toplantısı, vol. 1, Kültür ve Turizm Bakanlığı Yayınları, Kültür ve Turizm Bakanlığg DÖSİMM Basımevi, 471-480.

PULAK, C. 2008.

"The Uluburun Shipwreck and the Late Bronze Age Trade," Beyond Babylon: Art, Trade, and Diplomacy in the second millennium BC, New York: Metropolitan Museum of Art, 289-310.

STEFFY, L. C. 2012.

The Man Who Thought Like A Ship, Texas A\&M University Press.

TILDEN, F. 2007.

Interpreting Our Heritage, Chapel Hill: University of North Carolina Press.

WIENER, W. M. 1966.

Castles of the Crusaders, London: Thames \& Hudson. 
